\title{
The Asymmetric Total Synthesis of (+)- and (-)-Trypargine via Noyori Asymmetric Transfer Hydrogenation
}

\author{
Ronaldo A. Pilli* and Manoel Trindade Rodrigues Jr.
}

\author{
Instituto de Química, Universidade Estadual de Campinas, CP 6154, 13083-970 Campinas-SP, Brazil
}

\begin{abstract}
Uma síntese total e eficiente da (+) e (-)-tripargina, alcalóide $\beta$-carbolínico isolado da pele da rã africana $K$. Senegalensis, foi realizada em 6 etapas e $38 \%$ de rendimento global, a partir da triptamina, tendo como base a construção do sistema $\beta$-carbolínico via reação de BischlerNapieralski e a redução enantiosseletiva do intermediário diidro- $\beta$-carbolínico via reação de transferência de hidrogênio assimétrica usando o protocolo de Noyori.
\end{abstract}

A concise and efficient total synhesis of (+)- and (-)-trypargine (6 steps and $38 \%$ overall yield), a 1-substituted $\beta$-carboline guanidine alkaloid isolated from the skin of the African frog K. senegalensis, was developed based on the construction of the $\beta$-carboline moiety via BischlerNapieralski reaction and the enantioselective reduction of the dihydro- $\beta$-carboline intermediate via an asymmetric transfer hydrogenation reaction using Noyori's protocol.

Keywords: trypargine, tetrahydro $\beta$-carboline alkaloid, Bischler-Napieralski reaction, Noyori asymmetric transfer hydrogenation

\section{Introduction}

The $\beta$-carboline skeleton is widely distributed among natural products including yohimbine (yohimbine and alloyohimbine), corynantheidine (corynantheidine), Rauwolfia (reserpine) and Vinca (vincamine) alkaloids. ${ }^{1}$

(-)-Trypargine (1) is a $\beta$-carboline alkaloid which has been isolated from the skin of the African racophorid frog, Kassina senegalensis, by Akizawa et al. ${ }^{2}$ in 1982 and more recently has also been isolated in nearly racemic form from the methanol extract of the ground ascidian Eudistoma sp. ${ }^{3}$

The absolute configuration of natural (-)-trypargine (1) was initially assigned via resolution of its racemate, prepared via the Pictet-Spengler reaction between tryptamine and 4-guanidino butyraldehyde ethyleneacetal, followed by optical rotatory dispersion and circular dichroism studies. ${ }^{4}$ Ishikawa and co-workers ${ }^{4,5}$ established its absolute configuration by total synthesis via the Pictet-Spengler reaction between $(R)$ - $N$-benzyl tryptophan methyl ester and 2-ketoglutaric acid, followed by X-ray diffraction analysis of the corresponding methyl ester of the major diastereoisomer. Synthetic (-)-(S)-1-(3'-guanidinopropyl)-1,2,3,4-tetrahydro- $\beta$ carboline was shown to be identical to natural (-)-trypargine (1) thus establishing its absolute configuration.

*e-mail: pilli@iqm.unicamp.br
The presence of a $\beta$-carboline and a guanidine moieties in the structure of (-)-trypargine (1) has led to preliminary evaluation of its biological profile. Neither a full account of the biological properties nor its biosynthetic origin have been reported although one may envision trypargine (1) to be formed from tryptophan and the 2-keto carboxylic acid derived from arginine. It has been reported to be toxic to mice $\left(\mathrm{LD}_{50}=16.9 \mathrm{mg} \mathrm{kg}{ }^{-1}\right.$, intravenous administration) although complete details of this study are lacking. ${ }^{5,6}$ Ireland and co-workers ${ }^{3}$ have failed to observe significant cytotoxicity in fractions containing trypargine alkaloids against human colon tumor cells. Additionally, (-)-trypargine (1) has been reported to block voltage gated sodium channels in squid axon membrane. ${ }^{7}$

Our interest to further explore the biological profile of trypargine and analogues led us to consider the available methodologies for chirality transfer in order to develop a short and asymmetric route to these compounds which would secure enough quantities to carry out biological assessment. Our approach to a catalytic and asymmetric synthesis of (+)-trypargine (1) relied on our previous results on the enantioselective total syntheses of arborescidines when we successfully employed the Bischler-Napieralski protocol to assembly the 3,4-dihydro- $\beta$-carboline moiety, followed by the Noyori catalytic asymmetric hydrogen transfer reaction to reduce the intermediate prochiral 
imine. ${ }^{8}$ Recently, Drabowicz and co-workers ${ }^{9}$ disclosed the total synthesis of (+)-trypargine (1) via the latter approach which prompted us to disclose our results in this topic.

\section{Results and Discussion}

Our approach to $(R)$-trypargine (1) was based on the construction of the dihydro- $\beta$-carboline moiety via the Bischler-Napieralski reaction of tryptamine derivative $\mathbf{4}$ (Scheme 1). Among the routes evaluated to secure the preparation of intermediate 4 , two emerged as the most efficient: introduction of the 3-aminopropionyl group via Curtius rearrangement on 5-ketopentanoyl tryptamine (3, Scheme 1, step b) or via $N$-acylation of tryptamine (2) with $\mathrm{N}$-allyloxycarbonyl-4-aminobutyric acid (6, Scheme 1 , step d).

The thermolysis of acyl azides to the corresponding isocyanates is known as the thermal Curtius rearrangement and the reaction mechanism probably involves the concerted migration of the alkyl or aryl substituent in the carbonyl group to the nitrogen atom of the azido group with concomitant loss of dinitrogen. ${ }^{10-12}$ The isocyanate intermediate can be isolated when the reaction is carried out in non-nucleophilic solvent or can be intercepted by water, amines or alcohols to give the corresponding, amines, ureas or carbamates.

Starting from commercially available tryptamine (2), reaction with glutaric anhydride in acetone at room temperature provided the corresponding amide 3 in quantitative yield (Scheme 2). The Curtius rearrangement was carried out by treating a solution of amide $\mathbf{3}$ in acetone with methyl chloroformate in order to give rise to the corresponding mixed anhydride at $0{ }^{\circ} \mathrm{C}$ which was then converted to the corresponding acyl azide 7 upon treatment with aqueous sodium azide at $\mathrm{rt}$. Acyl azide 7 was heated in toluene for $2 \mathrm{~h}$ and the reaction was quenched by the addition of allylic alcohol to provide, after chromatography on silica gel, allyl carbamate $\mathbf{4}$ in $\mathbf{7 3 \%}$ overall yield from tryptamine (2).

Alternatively, allyl carbamate 4 was prepared in $88 \%$ yield via acylation of tryptamine (2) with $N$-carboallyloxy4-aminocarboxylic acid $\mathbf{6}$ and catalytic amount of $N$-hydroxybenzotriazol (HOBt) and 1-ethyl-3-(3dimethylaminopropyl)carbodiimide (EDCI) ${ }^{13}$ Despite the slight increase in the overall yield of allyl carbamate 4 , the use of expensive reagents in the method employing 4-amino butyric acid makes the Curtius rearrangement the method of choice for large scale preparation.

With the preparation of allyl carbamate 4 secured, the formation of dihydro- $\beta$-carboline $\mathbf{9}$ was succesfully carried out upon treating 4 with 3 equivalents of $\mathrm{POCl}_{3}$ in toluene/acetonitrile ( $7: 3, \mathrm{v} / \mathrm{v})$ under reflux, to give 9 in $76 \%$ yield after column chromatography. However, it proved to be more efficient to filter the crude reaction mixture through a pad of silica gel in order to remove most of the contaminants and proceed to the next step, the asymmetric transfer hydrogenation under the conditions described by Noyori and coworkers. Using the protocol, $(R)-(+)-\mathbf{1 0}$ was obtained in $75 \%$ overall yield from allyl carbamate 4 (Scheme 3).

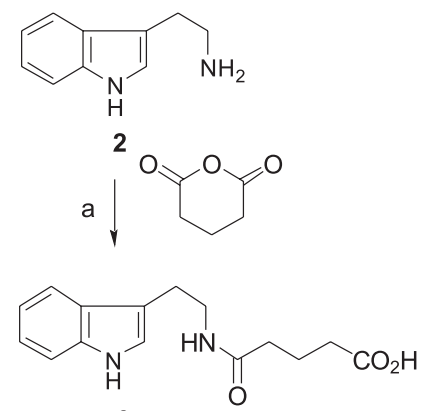

3

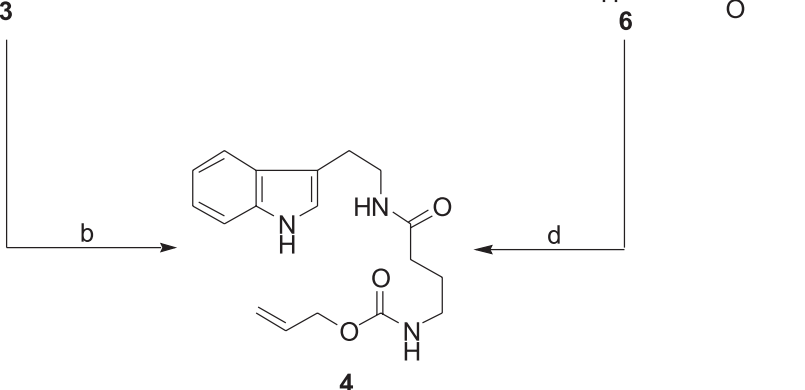<smiles>NCCCC(=O)O</smiles><smiles>C=CCOC(=O)Cl</smiles><smiles>C=CCOC(=O)NCCCC(=O)O</smiles>

Scheme 1. a) acetone, $20 \mathrm{~min}$., rt; b) i: methyl chloroformate, acetone, $0^{\circ} \mathrm{C}, 45 \mathrm{~min}$; ii: $\mathrm{NaN}_{3}, \mathrm{H}_{2} \mathrm{O}, 2 \mathrm{~h}$; iii: toluene, reflux, $2 \mathrm{~h}$; iv: allylic alcohol, reflux, $3 \mathrm{~h}, 73 \%$ (two steps); c) $\mathrm{NaHCO}_{3}, \mathrm{H}_{2} \mathrm{O}$, THF, rt. 24h, 100\%; d) 2, HOBt, EDCI, THF, rt, 16h, $88 \%$. 

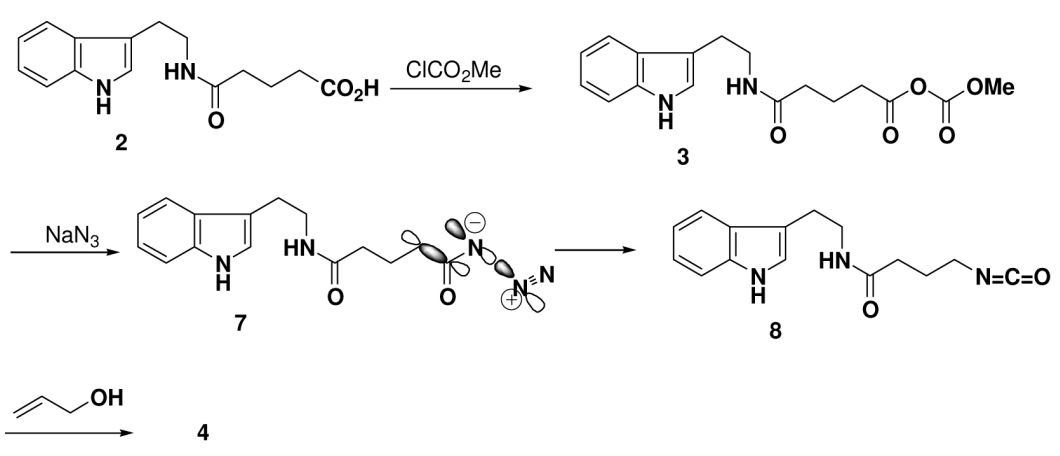

Scheme 2.

The Bischler-Napieralski reaction is a cyclodehydration which takes place when an acyl derivative of a $\beta$-arylethylamine is treated with a dehydrating agent. ${ }^{14,15}$ Mechanistic studies carried out by Fodor and coworkers have shown that the formation of imidoyl chloride and nitrilium intermediates is promoted by several dehydrating agents such as $\mathrm{POCl}_{3}, \mathrm{PCl}_{5}$ and $\mathrm{SOCl}_{2}{ }^{16,17}$ In our case, the formation of the imidoyl chloride or nitrilium salt from the indole amine would be followed by an aromatic electrophilic substitution to afford dihydro- $\beta$-carboline 9 (Scheme 4).

The asymmetric reduction of the prochiral imine 9 was efficiently carried out using the asymmetric transfer hydrogenation as devised by Noyori and co-workers. ${ }^{18}$ The reaction is catalyzed by chiral $N$-sulfonated diamine-Ru(II)- $\eta^{6}$ arene complexes and has become the method of choice for the enantioselective reduction of cyclic imines due to the high yield and enantiomeric excess usually attained and the simplicity of the experimental protocol..$^{1920}$ Despite the advantages of this methodology, relatively few examples of asymmetric synthesis of natural products containing the tetrahydro- $\beta$-carboline core have appeared since our first disclosure of the application of Noyori asymmetric transfer hydrogenation in the total synthesis of arborescidines A, B and C. ${ }^{8,9,21-23}$
The 16 electron catalytic active species II was generated upon treatment of pre-catalyst $\operatorname{RuCl}(S, S)$ $\mathrm{H}_{2} \mathrm{NCHPhCHPhNTs}$ )( $\eta$-p-cymene) (I) in DMF at $80{ }^{\circ} \mathrm{C}$ in the presence of $\mathrm{Et}_{3} \mathrm{~N} .{ }^{24,25}$ Then, a solution of prochiral imine 9 in DMF was added, followed by a 5:2 formic acid-triethylamine azeotropic mixture and the reaction mixture was kept at room temperature for $8 \mathrm{~h}$. Under these conditions tetrahydro- $\beta$-carboline $\mathbf{1 0}$ was isolated in $75 \%$ overall yield from allyl carbamate 4 . However, when longer reaction time was employed the hydrogenation of the allyloxy group present in $\mathbf{1 0}$ was also observed.

The proposed mechanism involves the six-membered arrangement IV which displays an hydrogen bond between the N-H in the chiral ligand and the nitrogen in the imine and hydride transfer from the ruthenium hydride species to the imine via an out-of-plane interaction between $\mathrm{Ru}-\mathrm{H}$ and the $\mathrm{C}=\mathrm{N}$ bonds. According to the working model proposed by Noyori and co-workers, ${ }^{18,19}$ the use of $(S, S)$-DPEN as the chiral ligand would direct the asymmetric transfer hydrogenation to take place at the Si face of prochiral imine $\mathbf{9}$ leading to $(R)-\mathbf{1 0}$ as the major enantiomer as depicted in Scheme 5.

Considering that the sense of chirality in the Noyori reduction would be validated by comparing the specific

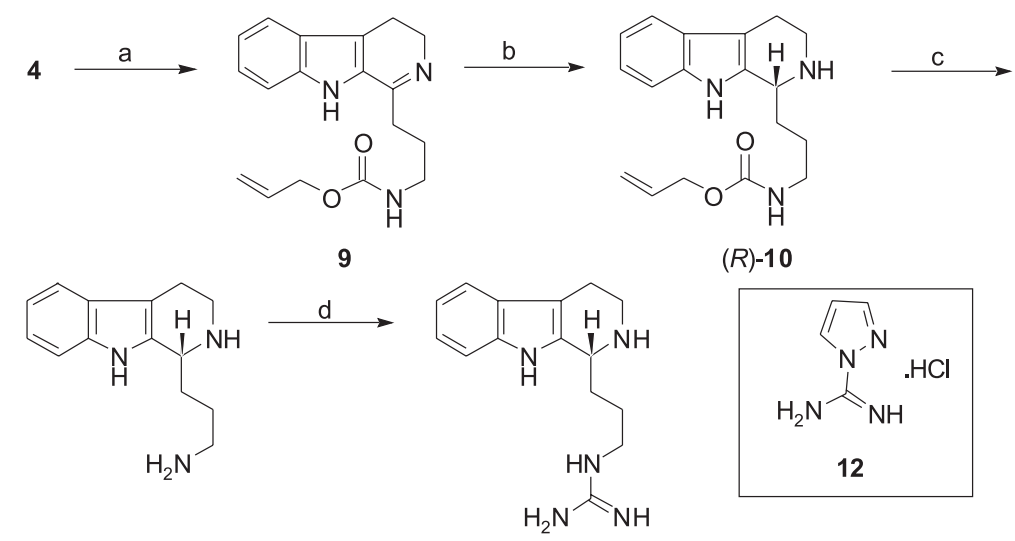

(R)-11

$(R)-1$

Scheme 3. a) $\mathrm{POCl}_{3}$, toluene/acetonitrile, reflux, 5h; b) (S,S)-TsDPEN-Rü, $\mathrm{HCO}_{2} \mathrm{H}_{-} \mathrm{Et}_{3} \mathrm{~N}(5: 2), \mathrm{DMF}, \mathrm{rt}, 8 \mathrm{~h}, 75 \%$ (two steps); c) Pd-C, Et ${ }_{3} \mathrm{SiH}, \mathrm{MeOH}$, $90 \%$; d) 12, DIPEA, DMF, rt, 24 h, then, $\mathrm{HCl} / \mathrm{MeOH}, 77 \%$. 


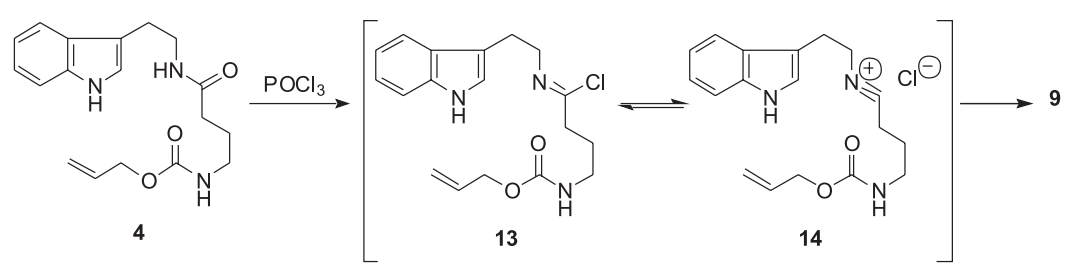

Scheme 4.

optical rotation of synthetic trypargine (1) with that described for trypargine isolated from natural sources, we focused on the determination of the enantiomeric ratio of tetrahydro- $\beta$-carboline $\mathbf{1 1}$ which was shown to be $98: 2$ after ${ }^{19} \mathrm{~F}-\mathrm{NMR}$ spectroscopic analyses of the Mosher amide prepared from $(R)-(-)-\alpha$-methoxy- $\alpha$-(trifluoromethyl) phenyl acetic acid (MTPA).

Our choice for the allyloxycarbonyl group in our synthetic scheme evolved after screening several different protecting groups (carbomethoxy, terc-butoxycarbonyl, benzyloxycarbonyl, 9-fluorenylmethoxycarbonyl and trifluorocarbonyl groups) as it proved to be compatible with the acidic conditions during the Bischler-Napieralski reaction using $\mathrm{POCl}_{3}$, the Noyori protocol for the transfer hydrogenation reaction and eventually it was easily removed under very mild conditions. In fact, by employing the conditions described by Mandal and McMurry, amine $(R)-\mathbf{1 1}$ was isolated in $90 \%$ yield after $30 \mathrm{~min}$ at $\mathrm{rt}$ in the presence of $\mathrm{Et}_{3} \mathrm{SiH}$ and catalytic amount of $\mathrm{Pd} / \mathrm{C}$ in ethanol. ${ }^{26}$

The final step toward $(R)$-trypargine $(\mathbf{1})$ was the introduction of the guanidine moiety which was carried out with the method described by Bernatowicz and co-workers ${ }^{4,9}$ which makes use of $1 H$-pyrazol1-carboxyamidine hydrochloride (12) in DMF and diisopropylethylamine. After column chromatography on basic alumina and treatment with methanolic $\mathrm{HCl},(R)$ - trypargine hydrochloride $(\mathbf{1} \cdot \mathrm{HCl})$ was isolated in $77 \%$ yield. Its physical (melting point and specific optical rotation) and spectroscopic data ( $\left({ }^{1} \mathrm{H}-\right.$ and ${ }^{13} \mathrm{C}-\mathrm{NMR}$ data) nicely matched those described in the literature.

Natural (S)-(-)-trypargine (1) was also prepared in 6 steps and 38\% overall yield from tryptamine according to the same reaction sequence.

The approach described herein is robust enough to provide trypargine and its derivatives in both enantiomeric forms in few steps, good overall yield and very high enantiomeric ratios from tryptamine and analogues and should be of value for the determination of the absolute configuration of others dihydro- $\beta$-carbolines such as the novel toxin isolated from the venom of the Parawixia bistriata spider endemic in the brazilian cerrado ${ }^{27}$ and pharmacological screening of related compounds.

\section{Experimental}

Commercially available reagents and solvents were previously purified. THF was distilled from calcium hydride and redistilled from sodium/benzophenone immediately prior to use. Dichloromethane, acetonitrile and triethylamine were distilled from calcium hydride immediately prior to use. Dimethylformamide (DMF) was distilled from calcium hydride under reduced pressure and

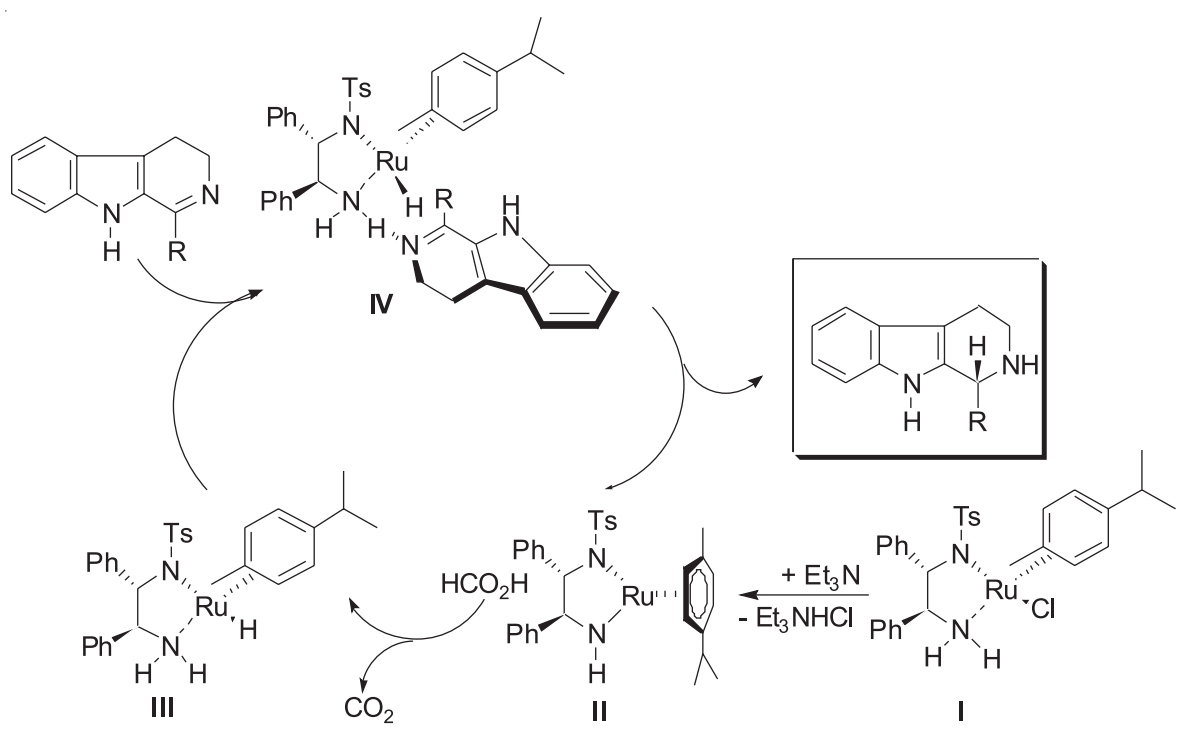

Scheme 5. 
temperature lower than $70^{\circ} \mathrm{C}$. Methanol was distilled from magnesium containing catalytic amount of iodine. $\mathrm{POCl}_{3}$ as distilled immediately prior to use.

The reactions were monitored with TLC plates (aluminum foils covered with silica gel) and exposed to UV radiation, followed by treatment with fosfomolibdic acid $(25 \%$ ethanolic solution) or aq. $\mathrm{KMnO}_{4}$ and heating on a hot plate. Chromatographic separations were carried out in silica gel (70-230 or 230-400 Mesh) or basic alumina (5-200 $\mu$ ).

Specific optical rotations were measured at $25{ }^{\circ} \mathrm{C}$ at $589 \mathrm{~nm}$ (sodium D line) and IR spectra were measured as film in $\mathrm{NaCl}$ cells and frequencies are reported as $\mathrm{cm}^{-1}$. Melting points are not corrected.

${ }^{1} \mathrm{H}$ - and ${ }^{13} \mathrm{C}$-NMR spectra were obtained in $\mathrm{CDCl}_{3}$ or $\mathrm{CD}_{3} \mathrm{OD}$ solutions at 250 and $62.5 \mathrm{MHz}$, respectively, or at 300 and $75 \mathrm{MHz}$, respectively. Chemical shifts $(\delta)$ were expressed in ppm and coupling constants in Hz. Multiplicity is reported as singlet (s), doublet (d), double dublets (dd), triplet (t), double triplet (dt), quartet (q), quintuplet (quint), multiplet (m) and broad singlet (br s).

\section{5-\{[2-(1H-Indol-3-yl)ethyl]amino\}-5-oxopentanoic acid (3)}

To a solution of glutaric anhydride $(0.10 \mathrm{~g}, 0.88 \mathrm{mmol})$ in acetone $(3 \mathrm{~mL})$, was added tryptamine $(0.15 \mathrm{~g}, 0.93$ mmol) dissolved in acetone $(0.5 \mathrm{~mL})$. The reaction mixture was stirred $20 \mathrm{~min}$ at $\mathrm{rt}$. The solvent was evaporated under reduced pressure and the crude reaction mixture was purified through a pad of silica gel and ethyl acetate as eluent to provide carboxylic acid 3 pure enough to be used in the next step. mp $138-139{ }^{\circ} \mathrm{C}$. IR (KBr) $v_{\max } / \mathrm{cm}^{-1}: 3400-2800,1709$, $1645,1543,1225,737 .{ }^{1} \mathrm{H}-\mathrm{NMR}\left(300 \mathrm{MHz}, \mathrm{CD}_{3} \mathrm{OD}\right) \delta 1.28$ (br s, 1H); 1.83-1.89 (m, 2H); 2.20 (t, J 6.5 Hz, 2H), 2.28 (t, $J 6.5 \mathrm{~Hz}, 2 \mathrm{H}) ; 2.93(\mathrm{t}, J 7.2 \mathrm{~Hz}, 2 \mathrm{H}) ; 3.47(\mathrm{t}, J 7.5 \mathrm{~Hz}, 2 \mathrm{H})$; 6.96-7.10 (m, 3H); 7.32 (d, J 7.5 Hz, 1H), 7.54 (d, J 7.5 Hz, 1H). ${ }^{13} \mathrm{C}-\mathrm{NMR}\left(75 \mathrm{MHz}, \mathrm{CD}_{3} \mathrm{OD}\right) \delta 22.4\left(\mathrm{CH}_{2}\right) ; 26.4\left(\mathrm{CH}_{2}\right)$; $34.2\left(\mathrm{CH}_{2}\right) ; 36.3\left(\mathrm{CH}_{2}\right) ; 41.5\left(\mathrm{CH}_{2}\right) ; 112.4(\mathrm{CH}) ; 113.4\left(\mathrm{C}_{0}\right)$; $119.4(\mathrm{CH}) ; 119.7(\mathrm{CH}) ; 122.4(\mathrm{CH}) ; 123.5(\mathrm{CH}) ; 128.9$ $\left(\mathrm{C}_{0}\right) ; 138.3\left(\mathrm{C}_{0}\right) ; 175.5\left(\mathrm{C}_{0}\right) ; 177.0\left(\mathrm{C}_{0}\right)$.

\section{Allyl (4-\{2-[1H-indol-3-yl)ethyl]amino)-4-oxobutyl) carbamate (4)}

To a solution of $3(0.27 \mathrm{~g}, 1.0 \mathrm{mmol})$ and triethylamine $(0.60 \mathrm{~mL})$ in acetone $(5 \mathrm{~mL})$ at $0{ }^{\circ} \mathrm{C}$ was added dropwise methyl chloroformate $(0.35 \mathrm{~mL}, 4.5 \mathrm{mmol})$. The reaction was stirred $45 \mathrm{~min}$ at $\mathrm{rt}$ and then a solution of sodium azide $(0.28 \mathrm{~g}, 4.3 \mathrm{mmol})$ in water $(1 \mathrm{~mL})$ was added. The reaction mixture was stirred $2 \mathrm{~h}$ at $\mathrm{rt}$ and then concentrated under reduced pressure (Caution! Do not concentrate to dryness to the risk of explosion.). The crude mixture was diluted in
$\mathrm{CH}_{2} \mathrm{Cl}_{2}(30 \mathrm{~mL})$ and washed with brine $(15 \mathrm{~mL})$. The organic phase was dried with anhydrous magnesium sulfate and the solvent was removed under reduced pressure (Caution! Do not concentrate to dryness due to the risk of explosion). The residue was dissolved in toluene $(20 \mathrm{~mL})$ and the solution was refluxed $2 \mathrm{~h}$ under nitrogen atmosphere when allylic alcohol $(0.38 \mathrm{~mL}, 5.6 \mathrm{mmol})$ was added and the reaction mixture was heated under reflux for $3 \mathrm{~h}$. The reaction mixture was purified by column chromatography on silica gel and ethyl acetate-hexanes $(1: 1, \mathrm{v} / \mathrm{v})$ as eluent to yield carbamate 4 a pale brown solid in $73 \%$ yield $(0.24 \mathrm{~g}, 0.70 \mathrm{mmol}) . \mathrm{mp}$ 84-86 ${ }^{\circ} \mathrm{C}$. IR (KBr) $v_{\max } / \mathrm{cm}^{-1}: 3305,1701,1643,1535,1257$. ${ }^{1} \mathrm{H}-\mathrm{NMR}\left(250 \mathrm{MHz}, \mathrm{CD}_{3} \mathrm{OD}\right) \delta 1.78$ (quint., $J 7.0 \mathrm{~Hz}, 2 \mathrm{H}$ ); $2.15(\mathrm{t}, J 7.0 \mathrm{~Hz}, 2 \mathrm{H}) ; 2.90(\mathrm{t}, J 7.0 \mathrm{~Hz}, 2 \mathrm{H}) ; 3.15$ (q, J 6.4 $\mathrm{Hz}, 2 \mathrm{H}) ; 3.54$ (q, J 6.4 Hz, 2H); 4.53 (d, J $5.5 \mathrm{~Hz}, 2 \mathrm{H}) ; 5.12-$ $5.32(\mathrm{~m}, 3 \mathrm{H}) ; 5.82-5.98(\mathrm{~m}, 1 \mathrm{H}) ; 6.05(\mathrm{sl}, 1 \mathrm{H}) ; 7.00-7.23$ (m, 3H); 7.32 (d, J 7.5 Hz, 1H), 7.64 (d, J 7.5 Hz, 1H); 8.50 (br s, $1 \mathrm{H}) .{ }^{13} \mathrm{C}-\mathrm{NMR}\left(62.5 \mathrm{MHz}, \mathrm{CD}_{3} \mathrm{OD}\right) \delta 20.8\left(\mathrm{CH}_{2}\right)$; $21.5\left(\mathrm{CH}_{2}\right) ; 29.2\left(\mathrm{CH}_{2}\right) ; 35.5\left(\mathrm{CH}_{2}\right) ; 36.1\left(\mathrm{CH}_{2}\right) ; 61.0\left(\mathrm{CH}_{2}\right)$; $106.9(\mathrm{CH}) ; 108.3(\mathrm{CH}) ; 112.7\left(\mathrm{C}_{0}\right) ; 114.2(\mathrm{CH}) ; 117.8(\mathrm{CH})$; $117.4\left(=\mathrm{CH}_{2}\right) ; 117.9(\mathrm{CH}) ; 123.0\left(\mathrm{C}_{0}\right) ; 128.8(\mathrm{CH}) ; 132.1$ $\left(\mathrm{C}_{0}\right) ; 152.2\left(\mathrm{C}_{0}\right) ; 168.3\left(\mathrm{C}_{0}\right)$. HRMS (ESI+) Found 330.1887 $[\mathrm{M}+\mathrm{H}]^{+}$; calc. for $\mathrm{C}_{18} \mathrm{H}_{24} \mathrm{~N}_{3} \mathrm{O}_{3}^{+}: 330.1812(+20.1$ ppm error).

\section{4-\{[(Allyloxy)carbonyl]amino\}butanoic acid (6)}

To a suspension of 4-aminobutyric acid $(0.46 \mathrm{~g}, 4.5 \mathrm{mmol})$ in THF $(10 \mathrm{~mL})$ containing sat. aq. $\mathrm{NaHCO}_{3}(10 \mathrm{~mL})$ at $0{ }^{\circ} \mathrm{C}$, was added dropwise allyl chloroformate $(0.5 \mathrm{~mL}$, $4.7 \mathrm{mmol})$. The reaction mixture was stirred $24 \mathrm{~h}$ at $\mathrm{rt}$ when conc. $\mathrm{HCl}$ was added dropwise to adjust to $\mathrm{pH} 2$. The reaction mixture was extracted with $\mathrm{CH}_{2} \mathrm{Cl}_{2}(3 \times 10 \mathrm{~mL})$ and the organic phase was dried under anhydrous magnesium sulfate. The carbamate 6 was obtained in quantitative yield as viscous oil which was used in the next step without further purification. IR $(\mathrm{KBr}) v_{\max } / \mathrm{cm}^{-1}: 3332,2947,1709$, 1538, 1255. ${ }^{1} \mathrm{H}-\mathrm{NMR}\left(250 \mathrm{MHz}, \mathrm{CDCl}_{3}\right) \delta 1.85$ (quint, $J 7.0 \mathrm{~Hz}, 2 \mathrm{H}) ; 2.38$ (t, J 7.2 Hz, 2H); 3.19-3.30 (m, 2H); 4.53 (d, J 5.2 Hz, 2H); 5.08 (br s, 1H); 5.23 (d, J $10.4 \mathrm{~Hz}$, $1 \mathrm{H}) ; 5.27$ (d, J 17.2 Hz, 1H); 5.89 (m, 1H); 7.55 (br s, 1H). ${ }^{13} \mathrm{C}-\mathrm{NMR}\left(62.5 \mathrm{MHz}, \mathrm{CDCl}_{3}\right) \delta 24.9\left(\mathrm{CH}_{2}\right) ; 31.1\left(\mathrm{CH}_{2}\right)$; $40.2\left(\mathrm{CH}_{2}\right) ; 65.6\left(\mathrm{CH}_{2}\right) ; 117.7\left(=\mathrm{CH}_{2}\right) ; 132.8(\mathrm{CH}) ; 156.5$ $\left(\mathrm{C}_{0}\right) ; 178.0\left(\mathrm{C}_{0}\right)$. HRMS (ESI+) Found $210.0773[\mathrm{M}+\mathrm{Na}]^{+}$; calc. for $\mathrm{C}_{8} \mathrm{H}_{13} \mathrm{NO}_{4} \mathrm{Na}^{+}$: 210.0742 (+14.8 ppm error).

\section{Allyl (4-\{2-[1H-indol-3-yl)ethyl]amino)-4-oxobutyl)} carbamate (4)

To a solution of $6(0.80 \mathrm{~g}, 4.3 \mathrm{mmol})$, HOBt $(0.23 \mathrm{~g}$, $1.7 \mathrm{mmol})$ and EDCI $(0.90 \mathrm{~g}, 4.7 \mathrm{mmol})$ in THF $(15 \mathrm{~mL})$ was added dropwise a solution of tryptamine $(0.80 \mathrm{~g}$, 
$5.0 \mathrm{mmol})$ in THF $(10 \mathrm{~mL})$. The reaction mixture was stirred $16 \mathrm{~h}$ at $\mathrm{rt}$, quenched with brine $(25 \mathrm{~mL})$ and extracted with ethyl acetate $(3 \times 25 \mathrm{~mL})$. The organic phase was dried over magnesium sulfate and evaporated under reduced pressure. After purification over a pad of silica gel with ethyl acetate as eluent, carbamate $\mathbf{4}$ was obtained in $88 \%$ yield (1.25 g, $3.78 \mathrm{mmol})$.

Allyl [3-(4,9-dihydro-3H-carbolin-1-yl)propyl]carbamate(9)

A solution of $4(1.18 \mathrm{~g}, 3.56 \mathrm{mmol})$ in a mixture $(7: 3 \mathrm{v} / \mathrm{v})$ of toluene/acetonitrile $(30 \mathrm{~mL})$ was added $\mathrm{POCl}_{3}(1 \mathrm{~mL}, 10 \mathrm{mmol})$ dropwise and the reaction mixture was refluxed for $5 \mathrm{~h}$. The reaction mixture was cooled to $\mathrm{rt}$ and concentrated under vacuum. The crude mixture was dissolved in $\mathrm{CH}_{2} \mathrm{Cl}_{2}(40 \mathrm{~mL})$ and washed with aq. $10 \% \mathrm{NH}_{4} \mathrm{OH}(25 \mathrm{~mL})$ and brine $(2 \times 25 \mathrm{~mL})$, successively. The organic phase was dried with anhydrous magnesium sulfate and concentrated under reduced pressure. After purification over a pad of silica gel with ethyl acetate/methanol $(10 \%, \mathrm{v} / \mathrm{v})$ as eluent, carbamate 9 was obtained in quantitative yield (1.11 g, $3.56 \mathrm{mmol}) .{ }^{1} \mathrm{H}-\mathrm{NMR}\left(250 \mathrm{MHz}, \mathrm{CDCl}_{3}\right) \delta 1.98$ (quint, $J 7.0 \mathrm{~Hz}, 2 \mathrm{H}) ; 2.74(\mathrm{t}, J 7.4 \mathrm{~Hz}, 2 \mathrm{H}) ; 2.85(\mathrm{t}, J$ $8.6 \mathrm{~Hz}, 2 \mathrm{H}) ; 3.26(\mathrm{q}, J 6.4 \mathrm{~Hz}, 2 \mathrm{H}) ; 3.84(\mathrm{t}, J 8.6 \mathrm{~Hz}$, $2 \mathrm{H}) ; 4.53(\mathrm{~d}, J 5.5 \mathrm{~Hz}, 2 \mathrm{H}) ; 5.16(\mathrm{dd}, J 1.4$ and $10.4 \mathrm{~Hz}$, $1 \mathrm{H}) ; 5.25(\mathrm{dd}, J 1.4$ and $17.2 \mathrm{~Hz}, 1 \mathrm{H}) ; 5.57(\mathrm{br}, 1 \mathrm{H})$; 5.78-5.93 (m, 1H); 7.10-7.16 (m, 1H); 7.23-7.29 (m, 1H); $7.40(\mathrm{~d}, J 8.2 \mathrm{~Hz}, 1 \mathrm{H}) ; 7.57$ (d, J 8.2 Hz, 1H). ${ }^{13} \mathrm{C}-\mathrm{NMR}$ $\left(62.5 \mathrm{MHz}, \mathrm{CDCl}_{3}\right) \delta 19.3\left(\mathrm{CH}_{2}\right) ; 27.0\left(\mathrm{CH}_{2}\right) ; 32.3\left(\mathrm{CH}_{2}\right)$; $40.7\left(\mathrm{CH}_{2}\right) ; 47.8\left(\mathrm{CH}_{2}\right) ; 65.6\left(\mathrm{CH}_{2}\right) ; 112.2(\mathrm{CH}) ; 117.0$ $\left(\mathrm{C}_{0}\right) ; 117.5\left(=\mathrm{CH}_{2}\right) ; 119.9(\mathrm{CH}) ; 120.1(\mathrm{CH}) ; 124.5(\mathrm{CH})$; $125.3\left(\mathrm{C}_{0}\right) ; 128.5\left(\mathrm{C}_{0}\right) ; 132.7(\mathrm{CH}) ; 137.0\left(\mathrm{C}_{0}\right) ; 156.9$ $\left(\mathrm{C}_{0}\right) ; 161.3\left(\mathrm{C}_{0}\right)$. HRMS (ESI+) Found $312.1722[\mathrm{M}+\mathrm{H}]^{+}$; calc. for $\mathrm{C}_{18} \mathrm{H}_{22} \mathrm{~N}_{3} \mathrm{O}_{2}^{+}: 312.1707$ (+3.2 ppm error).

Allyl \{3-[(1R)-2,3,4,9-tetrahydro-1H- $\beta$-carbolin- $1-y l]$ propyl\}carbamate (10)

To a previously dried round-bottomed flask was added $\mathrm{RuCl}_{2}$ (n-p-cymene) $(5.4 \mathrm{mg}, 8.8 \mu \mathrm{mol}),(S, S)$-TsDPEN $(6.4 \mathrm{mg}, 17.5 \mu \mathrm{mol})$, triethylamine $(1.3 \mu \mathrm{L}, 17.6 \mu \mathrm{mol})$ and dry DMF $(2.0 \mathrm{~mL})$ was heated $1 \mathrm{~h}$ at $80{ }^{\circ} \mathrm{C}$. The mixture was cooled to $\mathrm{rt}$ and a solution of $9(0.59 \mathrm{~g}, 1.9 \mathrm{mmol})$ in DMF $(2 \mathrm{~mL})$ was added followed by the addition of an azeotropic mixture of formic acid and triethylamine $(1.0 \mathrm{~mL}, 5: 2 \mathrm{v} / \mathrm{v})$. The reaction mixture was kept $8 \mathrm{~h}$ at $\mathrm{rt}$ and then DMF was distilled under reduced pressure and the crude product was purified by column chromatography on silica gel $\left(20 \% \mathrm{CHCl}_{3} / \mathrm{MeOH}, \mathrm{v} / \mathrm{v}\right)$ to afford $(0.45 \mathrm{~g}$, $1.42 \mathrm{mmol}$ ) in $75 \%$ yield as a viscous yellow oil. $[\alpha]_{\mathrm{D}}^{20}+27.0$ (c 1.0, MeOH). ${ }^{1} \mathrm{H}-\mathrm{NMR}\left(250 \mathrm{MHz}, \mathrm{CD}_{3} \mathrm{OD}\right) \delta 1.14-1.34$ (m, 2H); 1.69-2.01 (m, 3H); 2.13-2.23 (m, 1H); 2.85-3.02 (m, 2H); 3.20-3.25 (m, 2H); 4.51-4.53 (m, 2H); 5,16 (dd, J 1.4 and $10.4 \mathrm{~Hz}, 1 \mathrm{H}) ; 5.28$ (dd, $J 1.4$ and $17.2 \mathrm{~Hz}, 1 \mathrm{H}) ; 5.92$ (m, 1H); 7.00-7.14 (m, 2H); 7.34 (d, J 8.0 Hz, 1H); 7.44 $(\mathrm{d}, J 8.0 \mathrm{~Hz}, 1 \mathrm{H}) .{ }^{13} \mathrm{C}-\mathrm{NMR}\left(62.5 \mathrm{MHz}, \mathrm{CD}_{3} \mathrm{OD}\right) \delta 20.5$ $\left(\mathrm{CH}_{2}\right) ; 27.0\left(\mathrm{CH}_{2}\right) ; 31.2\left(\mathrm{CH}_{2}\right) ; 41.4\left(\mathrm{CH}_{2}\right) ; 43.2\left(\mathrm{CH}_{2}\right) ; 54.4$ $(\mathrm{CH}) ; 66.5\left(\mathrm{CH}_{2}\right) ; 107.0\left(\mathrm{C}_{0}\right) ; 112.4(\mathrm{CH}) ; 117.6\left(=\mathrm{CH}_{2}\right)$; $119.0(\mathrm{CH}) ; 120.4(\mathrm{CH}) ; 123.2(\mathrm{CH}) ; 127.8\left(\mathrm{C}_{0}\right) ; 131.9$ $(\mathrm{CH}) ; 134.6\left(\mathrm{C}_{0}\right) ; 138.2\left(\mathrm{C}_{0}\right) ; 159.0\left(\mathrm{C}_{0}\right)$. HRMS (ESI+) Found $314.1835[\mathrm{M}+\mathrm{H}]^{+}$; calc. for $\mathrm{C}_{18} \mathrm{H}_{24} \mathrm{~N}_{3} \mathrm{O}_{2}^{+}: 314.1869$ (-10.8 ppm error).

Allyl \{3-[(1S)-2,3,4,9-tetrahydro-1H- $\beta$-carbolin- 1 -yl] propyl) carbamate (10)

The reaction was carried out as described above for $(R)$ 10 , except that the catalyst was prepared using (S)-TsDPEN instead of $(R)$-TsDPEN. $[\alpha]_{\mathrm{D}}^{20}-28.0$ (c 1.0, MeOH).

\section{$\{3-[(1 R)-2,3,4,9$-tetrahydro-1H- $\beta$-carbolin-1-yl)propyl $\}$ amine (11)}

To a previously dried round-bottomed flask containing $(R)-10(0.30 \mathrm{~g}, 0.95 \mathrm{mmol}), 5 \% \mathrm{Pd} / \mathrm{C}(0.03 \mathrm{~g})$ and methanol $(15 \mathrm{~mL})$ at $\mathrm{rt}$ was added dropwise triethylsilane $(0.75 \mathrm{~mL}$, $4.7 \mathrm{mmol}$ ). The reaction mixture was stirred $30 \mathrm{~min}$ at $\mathrm{rt}$ and filtered to remove the catalyst. The solvent was removed under reduced pressure and the crude product was purified on basic alumina (ethyl acetate and $20 \%$ ethyl acetate/methanol as eluents) to afford pale brown oil $(0.20 \mathrm{~g}, 0.85 \mathrm{mmol})$ in $90 \%$ yield. $[\alpha]_{\mathrm{D}}^{20}+75.0$ (c $\left.1.0, \mathrm{MeOH}\right), \mathrm{IR}(\mathrm{KBr})$ $v_{\max } / \mathrm{cm}^{-1}: 3453$ and 3245. ${ }^{1} \mathrm{H}-\mathrm{NMR}\left(250 \mathrm{MHz}, \mathrm{CD}_{3} \mathrm{OD}\right)$ $\delta 1.60-1.76(\mathrm{~m}, 2 \mathrm{H}) ; 1.96-2.07(\mathrm{~m}, 2 \mathrm{H}) ; 2.65-2.78(\mathrm{~m}, 4 \mathrm{H})$; 2.90-2.98 (m, 2H); 4.01-4.05 (m, 1H); 6.95-7.10 (m, 2H); 7.29-7.41 (m, 2H). ${ }^{13} \mathrm{C}-\mathrm{NMR}\left(62.5 \mathrm{MHz}, \mathrm{CD}_{3} \mathrm{OD}\right) \delta 22.4$ $\left(\mathrm{CH}_{2}\right) ; 25.6\left(\mathrm{CH}_{2}\right) ; 32.9\left(\mathrm{CH}_{2}\right) ; 40.9\left(\mathrm{CH}_{2}\right) ; 43.2\left(\mathrm{CH}_{2}\right) ; 53.5$ $(\mathrm{CH}) ; 109.2\left(\mathrm{C}_{0}\right) ; 112.7(\mathrm{CH}) ; 118.8(\mathrm{CH}) ; 120.0(\mathrm{CH})$; $122.5(\mathrm{CH}) ; 128.5\left(\mathrm{C}_{0}\right) ; 135.0\left(\mathrm{C}_{0}\right) ; 138.0\left(\mathrm{C}_{0}\right)$.

\section{$\{3-[(1 S)-2,3,4,9-$ tetrahydro- $1 H-\beta$-carbolin-1-yl)propyl $\}$ amine (11)}

The same procedure as described above was employed to afford $(S)-11$ in $87 \%$ yield $[\alpha]_{\mathrm{D}}^{20}-74.0$ (c 1.0, $\mathrm{MeOH}$ ).

\section{(+)-(R)-Trypargine Hydrochloride (1a)}

To a solution of $(R)-11(0.110 \mathrm{~g}, 0.5 \mathrm{mmol})$ in DMF (1 mL) was added pyrazole $12(0.075 \mathrm{~g}, 0.5 \mathrm{mmol})$ and diisopropylethylamine $(0.25 \mathrm{~mL}, 1.4 \mathrm{mmol})$. The reaction 
mixture was stirred $24 \mathrm{~h}$ at $\mathrm{rt}$ when DMF was removed under reduced pressure. The crude product was purified by column chromatography on basic alumina (chloroform/ methanol $30 \%, \mathrm{v} / \mathrm{v})$ to afford $(+)-(R)$-trypargine $(0.104 \mathrm{~g}$, $0.38 \mathrm{mmol}$ ) in $77 \%$ yield as a yellow solid which was treated with methanolic $\mathrm{HCl}$ to obtain $(+)-(R)$-trypargine hydrochloride as a yellow solid. mp $213-214{ }^{\circ} \mathrm{C} ;[\alpha]_{\mathrm{D}}{ }^{20}+32$ (c 1.0, MeOH); \{lit. ${ }^{9}: 210-213^{\circ} \mathrm{C} ;[\alpha]_{\mathrm{D}}^{23}+34.3$ (c 1.0, $\mathrm{MeOH})\} . \mathrm{IR}(\mathrm{KBr}) v_{\max } / \mathrm{cm}^{-1}: 3350,2934,1660 .{ }^{1} \mathrm{H}-\mathrm{RMN}$ (250 MHz, CD $\mathrm{OD}) \delta 1.87-1.96(\mathrm{~m}, 2 \mathrm{H}) ; 2.01-2.10(\mathrm{~m}$, $1 \mathrm{H}) ; 2.30-2.40(\mathrm{~m}, 1 \mathrm{H}) ; 2.85-3.15(\mathrm{~m}, 2 \mathrm{H}) ; 3.28-3.50(\mathrm{~m}$, $3 \mathrm{H}) ; 3.67-3.71(\mathrm{~m}, 1 \mathrm{H}) ; 4.70-4.78(\mathrm{~m}, 1 \mathrm{H}) ; 7.04$ (t, J 7.2 $\mathrm{Hz}, 1 \mathrm{H}) ; 7.14$ (t, J 7.2 Hz, 1H); $7.38(\mathrm{~d}, J 8.0 \mathrm{~Hz}, 1 \mathrm{H})$; $7.47(\mathrm{~d}, J 8.0 \mathrm{~Hz}, 1 \mathrm{H}) .{ }^{13} \mathrm{C}-\mathrm{NMR}\left(62.5 \mathrm{MHz}, \mathrm{CD}_{3} \mathrm{OD}\right)$ $\delta 19.4\left(\mathrm{CH}_{2}\right) ; 25.8\left(\mathrm{CH}_{2}\right) ; 30.5\left(\mathrm{CH}_{2}\right) ; 42.0\left(\mathrm{CH}_{2}\right) ; 43.0$ $\left(\mathrm{CH}_{2}\right) ; 54.4(\mathrm{CH}) ; 107.4\left(\mathrm{C}_{0}\right) ; 112.4(\mathrm{CH}) ; 119.1(\mathrm{CH})$; $120.6(\mathrm{CH}) ; 123.5(\mathrm{CH}) ; 127.3\left(\mathrm{C}_{0}\right) ; 129.7\left(\mathrm{C}_{0}\right) ; 138.3\left(\mathrm{C}_{0}\right)$; $158.6\left(\mathrm{C}_{0}\right)$. HRMS (ESI+) Found $272.1884[\mathrm{M}+\mathrm{H}]^{+}$; calc. for $\mathrm{C}_{15} \mathrm{H}_{22} \mathrm{~N}_{5}^{+}: 272.1875$ (+3.3 ppm error).

\section{(-)-(S)-Trypargine Hydrochloride (1b)}

The same procedure as above was employed starting from $(S)$-3-(2,3,4,9-tetrahydro-1 $H$-pyrido[3,4-b]indol1-yl)propan-1-amine (11b) to afford (-)-(S)-trypargine hydrochloride (1) in 78\% yield, $[\alpha]_{\mathrm{D}}^{20}+34(1.0, \mathrm{MeOH})$.

\section{Acknowledgments}

This work was supported by FAPESP (research grant and fellowship to M. T. R.) and CNPq (fellowship to R. A. P.).

\section{Supplementary Information}

Supplementary data are available free of charge at http:// jbcs.sbq.org.br, as pdf file.

\section{References}

1. Szantay, C. In The Alkaloids. Chemistry and Biology; Cordell, G. A., ed., Academic Press: , 1998, vol. 50, pp. 337-414.

2. Akizawa, T.; Yamasaki, T.; Yasuhara, T.; Nakajima, T.; Roseghini, M.; Ersparmer, G. F.; Ersparmer, V.; Biomed. Res. 1982, 3, 232.

3. Van Wagoner, R. M.; Jompa, J.; Tahir, A.; Ireland, C. M.; J. Nat. Prod. 1999, 62, 794.
4. Shimizu, M.; Ishikawa, M.; Komoda,Y.; Nakajima, T.; Chem. Pharm. Bull. 1982, 30, 909.

5. Shimizu, M.; Ishikawa, M.; Komoda, Y.; Nakajima, T.; Yamaguchi, K.; Sakai, S.; Chem. Pharm. Bull. 1982, 30, 3453.

6. Shimizu, M.; Ishikawa, M.; Komoda, Y.; Nakajima, T.; Yamaguchi, K.; Sakai, S. Chem. Pharm. Bull. 1984, 32, 1313.

7. Seyama, L.; Yakehiro, M.; Nakajima, T.; Japan J. Physiol. 1985 , $35,367$.

8. Santos, L. S.; Pilli, R. A.; Rawal, V. H.; J. Org. Chem. 2004, 69, 1283.

9. Czarnocki, S.J.; Wojtasiewicz, K.; Józwiak, A. P.; Maurin, J. K.; Czarnocki, Z.; Drabowicz, J.; Tetrahedron 2008, 64, 3176.

10. Smith, P. A. S.; Org. React. 1946, 337.

11. Scriven, E. F. V.; Turnbull, K.; Chem. Rev. 1988, 88, 297.

12. Linke, S.; Tisue, G. T.; Lwowski, W.; J. Am. Chem. Soc. 1967, $89,6308$.

13. Chan, L. C.; Cox, B. G.; J. Org. Chem. 2007, 72, 8863.

14. Whaley, W. M.; Govindachari, T. R.; Org. React. 1951, 6, 74.

15. Lorsbach, B. A.; Kurth, M. J.; Chem. Rev. 1999, 99, 1549.

16. Fodor, G.; Nagubandi, S.; Tetrahedron 1980, 36, 1279.

17. Fodor, G.; Gal, J.; Phillips, A.; Angew. Chem., Int. Ed. 1972, $26,919$.

18. Uematsu, N.; Fujii, A.; Hashigushi, S.; Ikaryia, T.; Noyori, R.; J. Am. Chem. Soc. 1996, 118, 4916.

19. Noyori, R.; Hashigushi, S.; Acc. Chem. Res. 1997, $30,97$.

20. Samec, J. S. M.; Bäckvall, J-E.; Andersson, P. G.; Brandt, P.; Chem. Soc. Rev. 2006, 35, 237.

21. Tietze, L. F.; Rackelmann, N.; Müller, I.; Chem. Eur. J. 2004, 10, 2722.

22. Szawkalo, J.; Czarnocki, S. J.; Zawadzka, A.; Wojtasiewicz, K.; Leniewski, A.; Maurin, J. K.; Czarnock, Z.; Drabowicz, J.; Tetrahedron: Asymmetry 2007, 18, 406.

23. Shankaraiah, N.; da Silva, W. A.; Andrade, C. K. Z.; Santos, L. S.; Tetrahedron Lett. 2008, 49, 4289.

24. Clapham, S. E.; Hadzovic, A.; Morris, R. H.; Coord. Chem. Rev. 2004, 248, 2201.

25. Fujii, A; Hashiguchi, S; Uematsu, N; Ikariya, T.; Noyori, R.; J. Am. Chem. Soc. 1996, 118, 2521.

26. Mandal, P. K.; McMurray, J. S.; J .Org. Chem. 2007, 72, 6599.

27. Cesar, L. M. M.; Mendes, M. A.; Tormena, C. F.; Marques, M. R.; de Souza, B. M.; Saidemberg, D. M.; Bittencourt, J. C.; Palma, M. S.; Toxicon 2005, 46, 786.

Received: December 5, 2008

Web Release Date: August 12, 2009

FAPESP helped in meeting the publication costs of this article. 


\section{The Asymmetric Total Synthesis of (+)- and (-)-Trypargine via Noyori Asymmetric Transfer Hydrogenation}

Ronaldo A. Pilli* and Manoel Trindade Rodrigues Jr.

Instituto de Química, Universidade Estadual de Campinas, CP 6154, 13083-970 Campinas-SP, Brazil

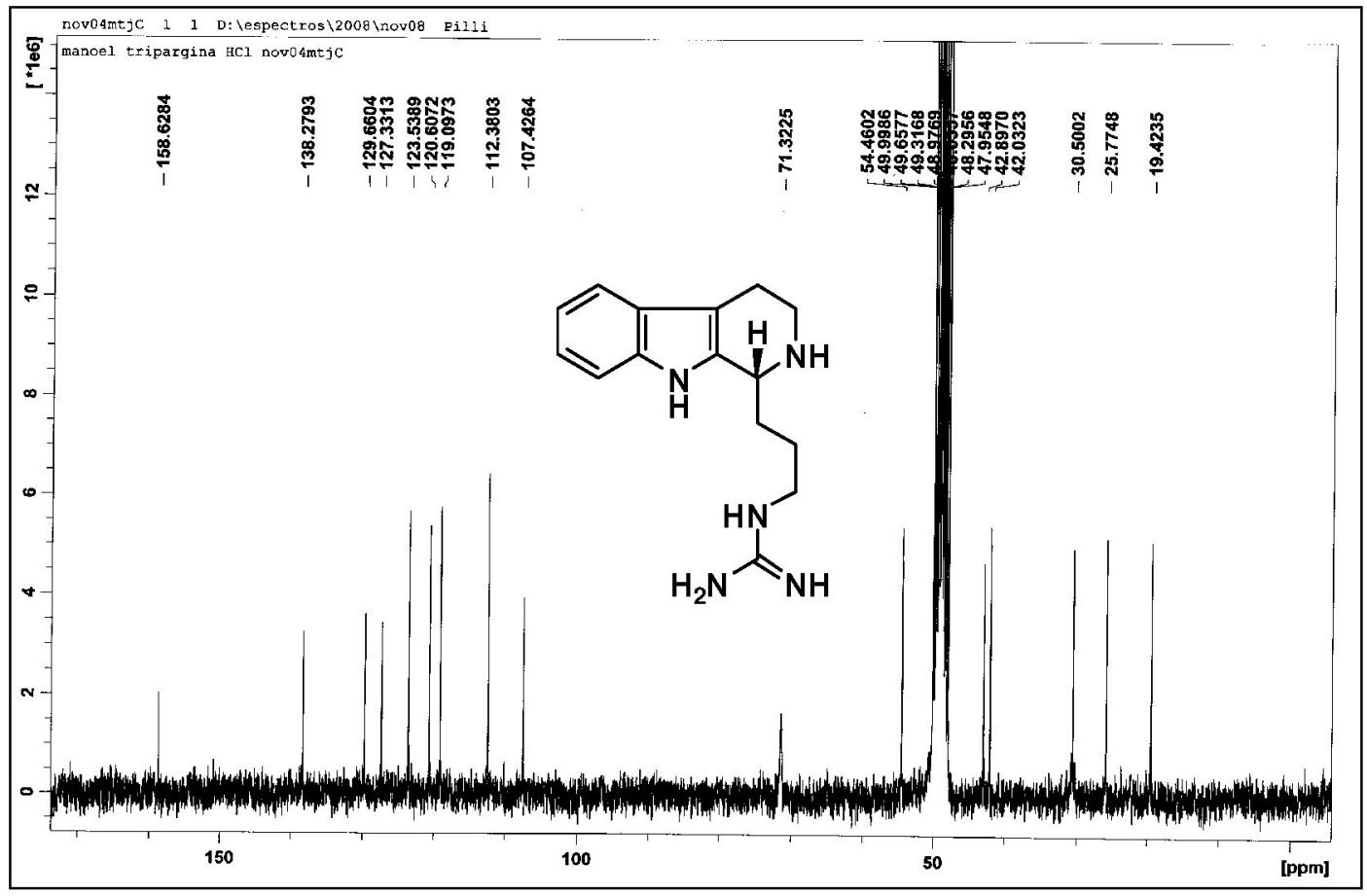

Figure S1. ${ }^{1} \mathrm{H}$ NMR for compound $3\left(300 \mathrm{MHz}, \mathrm{CD}_{3} \mathrm{OD}\right)$. 
(+)-(R)-Trypargine Hydrochloride (1a)

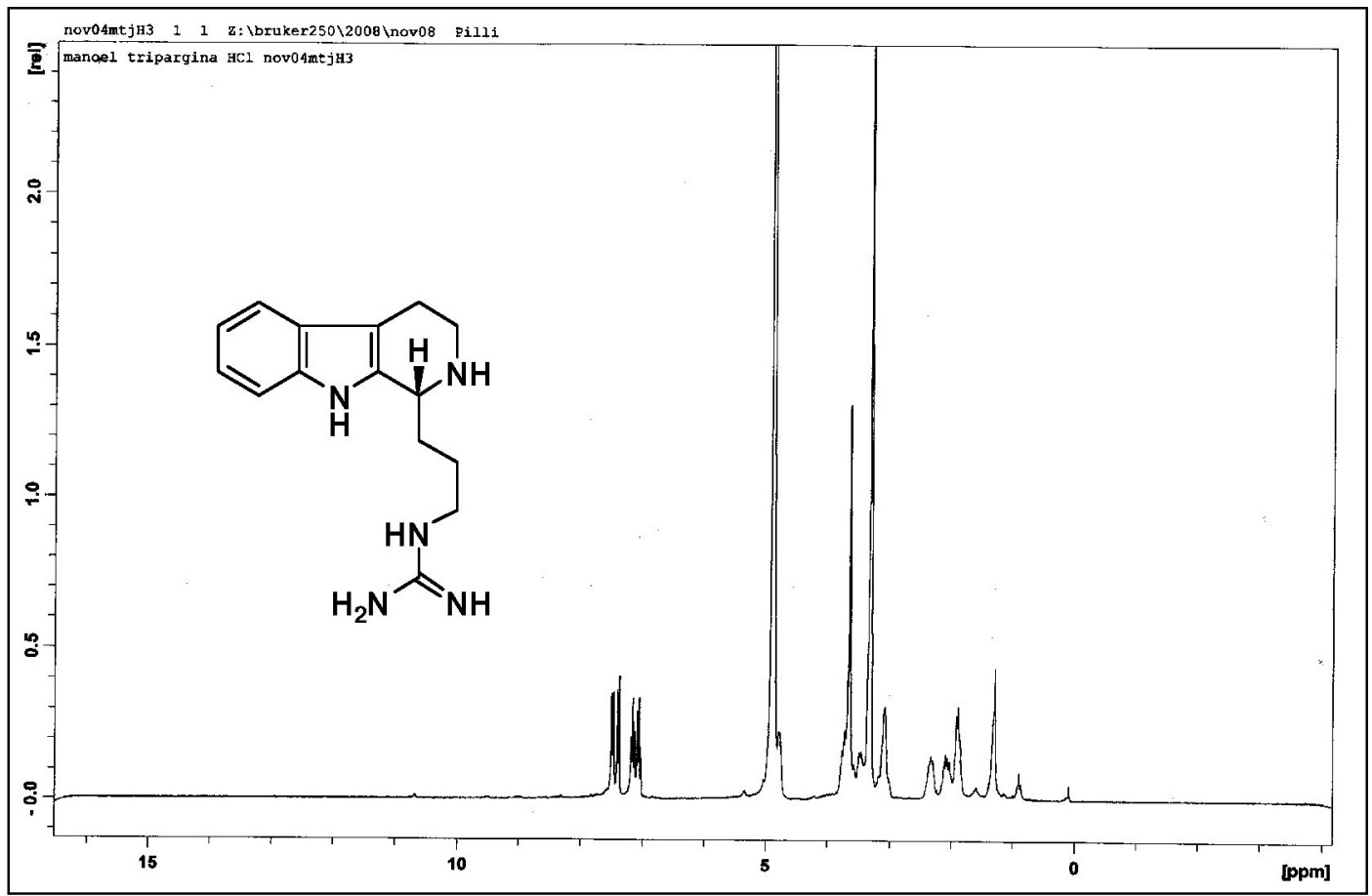

Figure S2. ${ }^{13} \mathrm{C}$ NMR for compound $3\left(75 \mathrm{MHz}, \mathrm{CD}_{3} \mathrm{OD}\right)$.

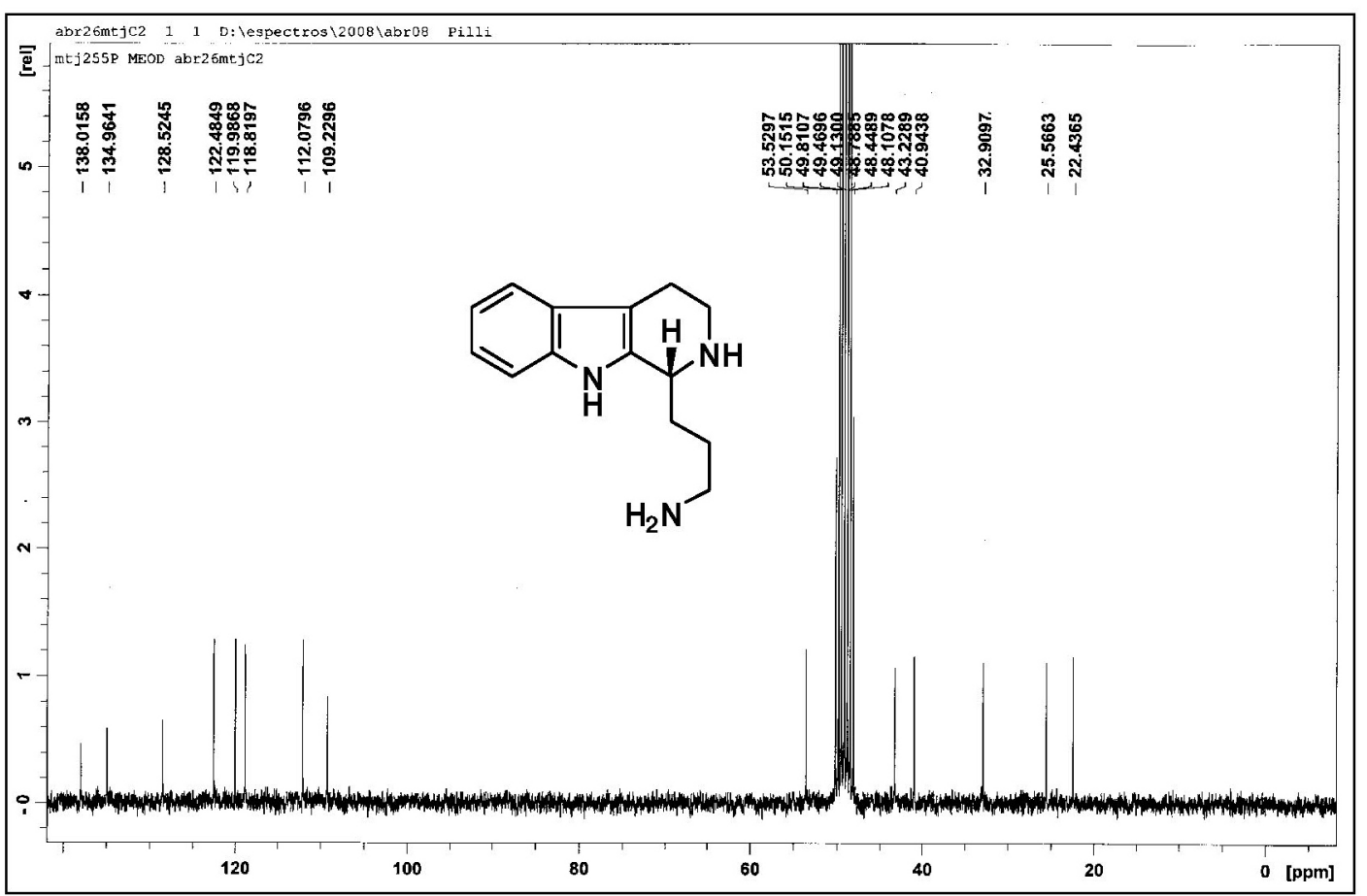

Figure S3. ${ }^{1} \mathrm{H}$ NMR for compound $4\left(250 \mathrm{MHz}, \mathrm{CD}_{3} \mathrm{OD}\right)$. 
$\{3-[(1 \mathrm{R})-2,3,4,9$-tetrahydro- $1 H$ - $\beta$-carbolin-1-yl)propyl $\}$ amine (11a)

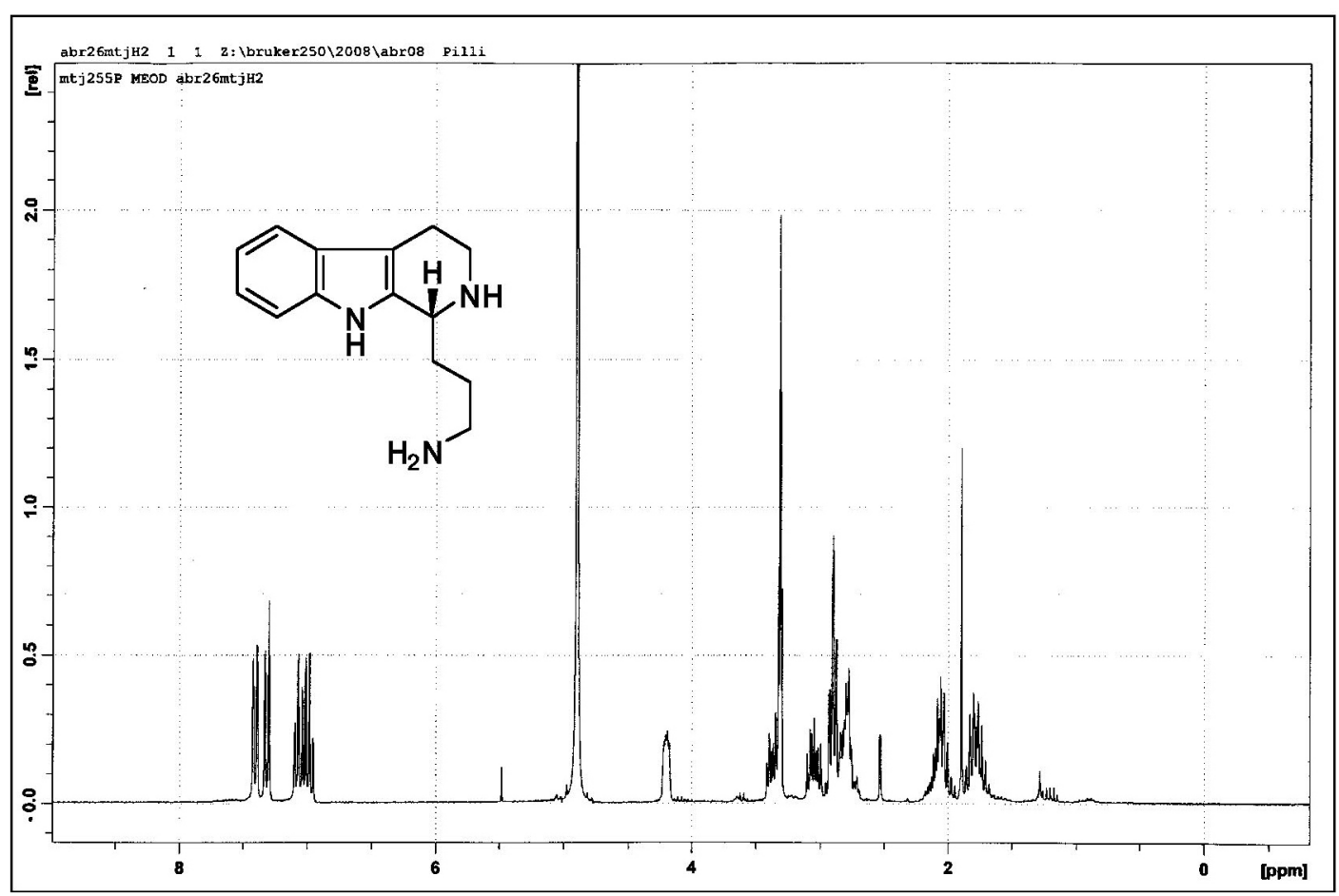

Figure S4. ${ }^{13} \mathrm{C}$ NMR for compound $4\left(62,5 \mathrm{MHz}, \mathrm{CD}_{3} \mathrm{OD}\right)$.

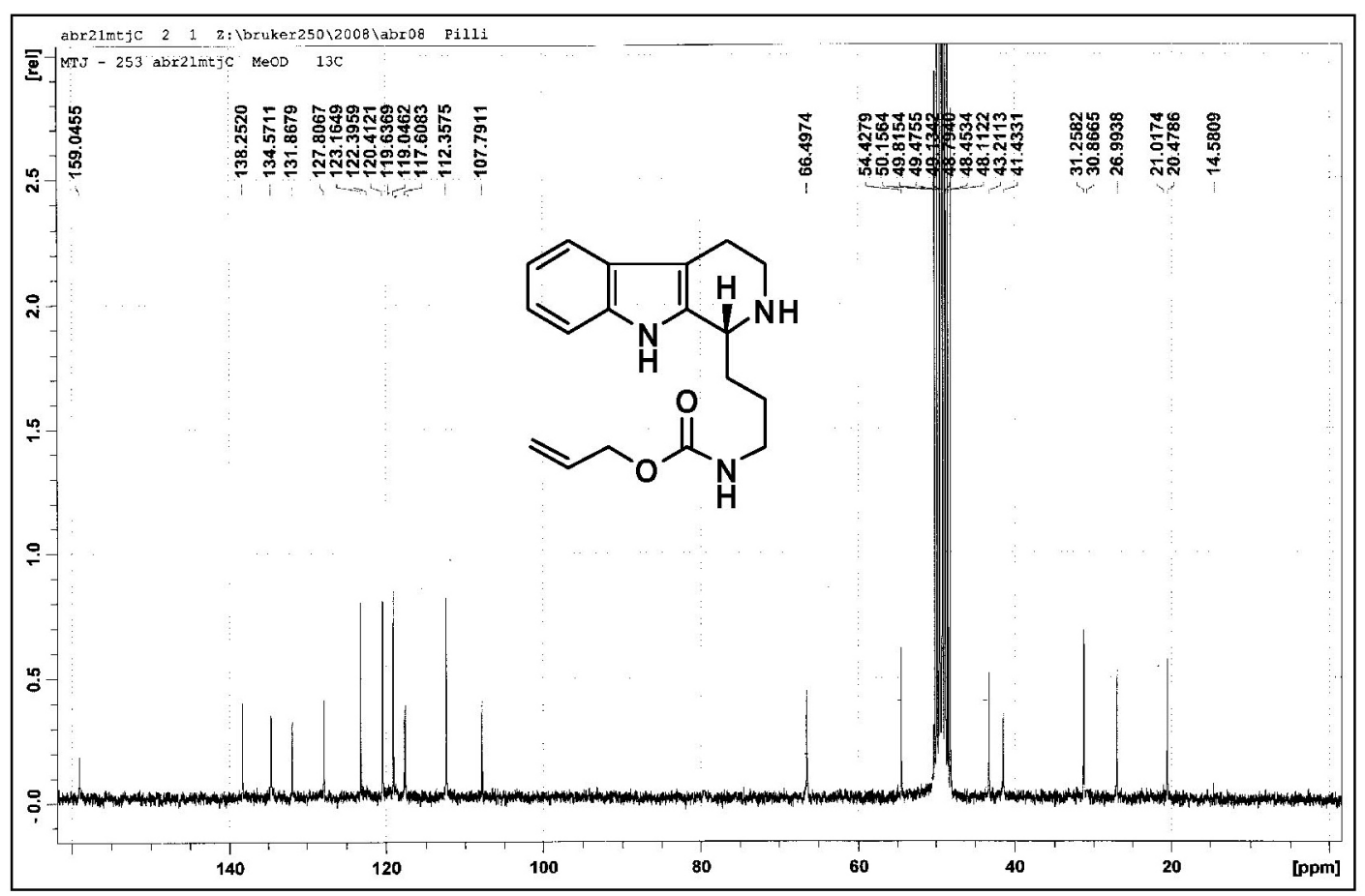

Figure S5. ' $\mathrm{H}$ NMR for compound $6\left(250 \mathrm{MHz}, \mathrm{CDCl}_{3}\right)$. 
Allyl $\{3-[(1 \mathrm{R})-2,3,4,9$-tetrahydro- $1 H$ - $\beta$-carbolin-1-yl]propyl $\}$ carbamate (10a)

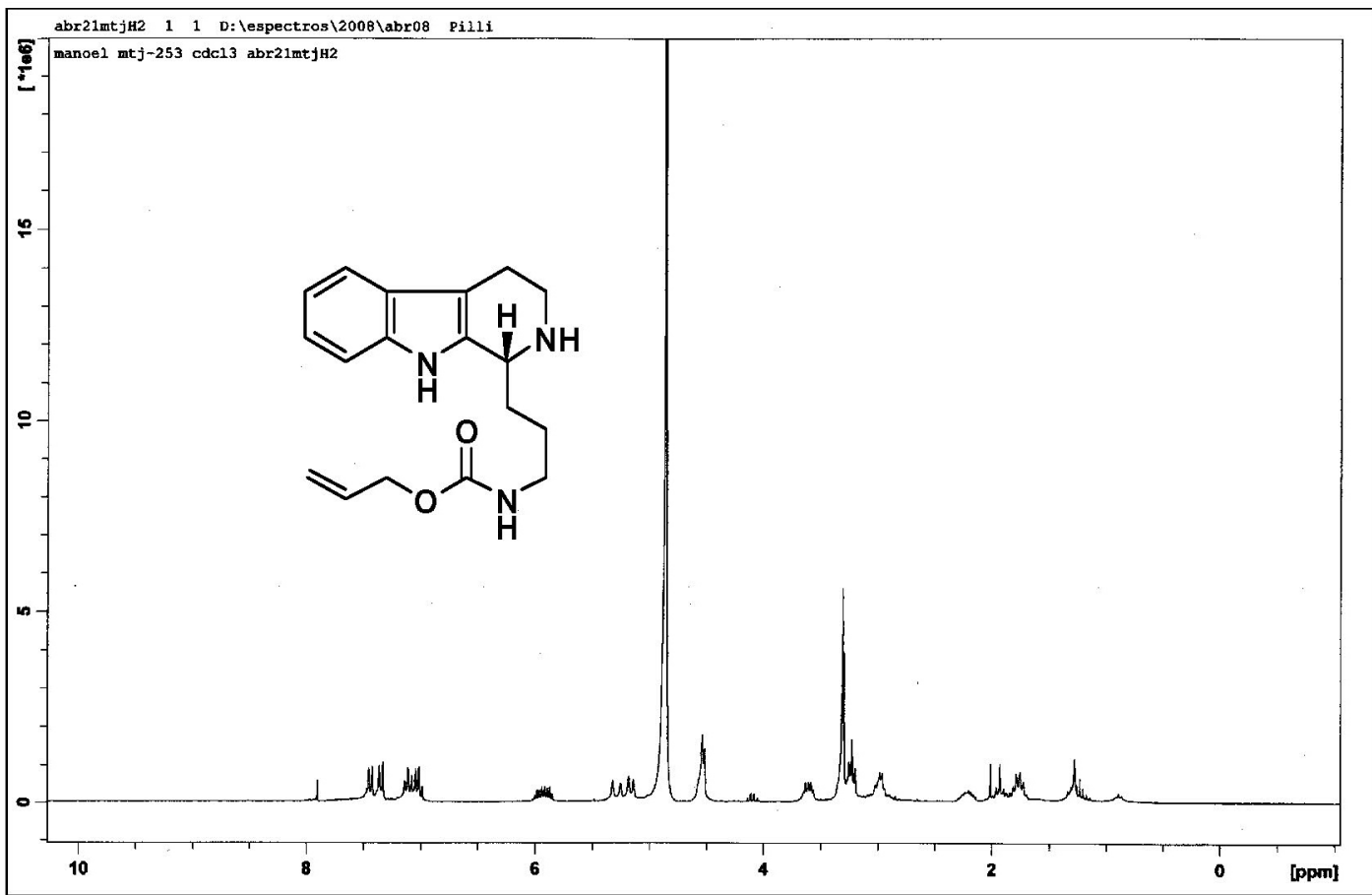

Figure S6. ${ }^{13} \mathrm{C}$ NMR for compound $6\left(62,5 \mathrm{MHz} \mathrm{CDCl}_{3}\right)$.

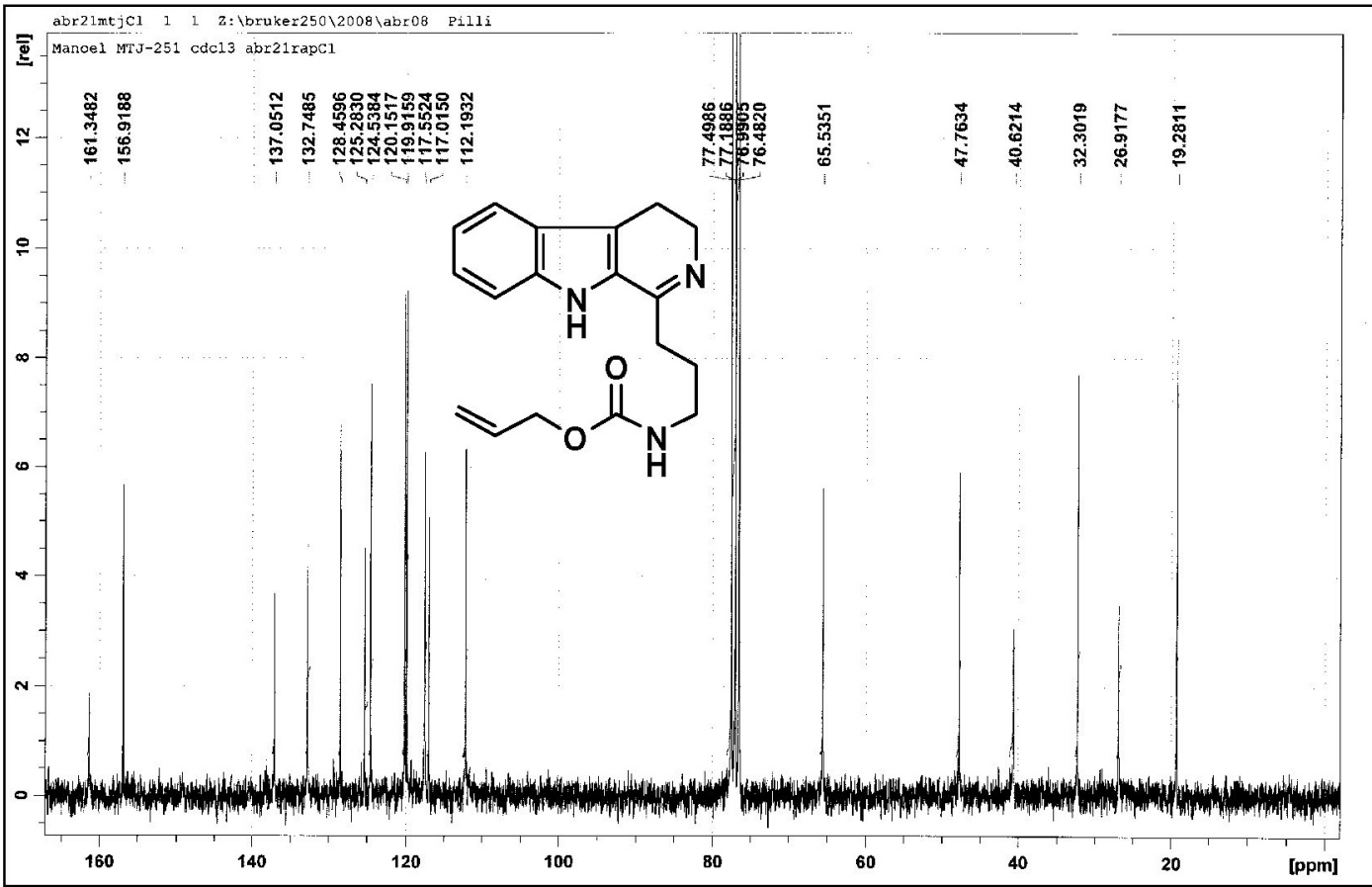

Figure S7. ${ }^{1} \mathrm{H}$ NMR for compound $9\left(250 \mathrm{MHz}, \mathrm{CDCl}_{3}\right)$. 
Allyl [3-(4,9-dihydro-3H-carbolin-1-yl)propyl]carbamate (9)

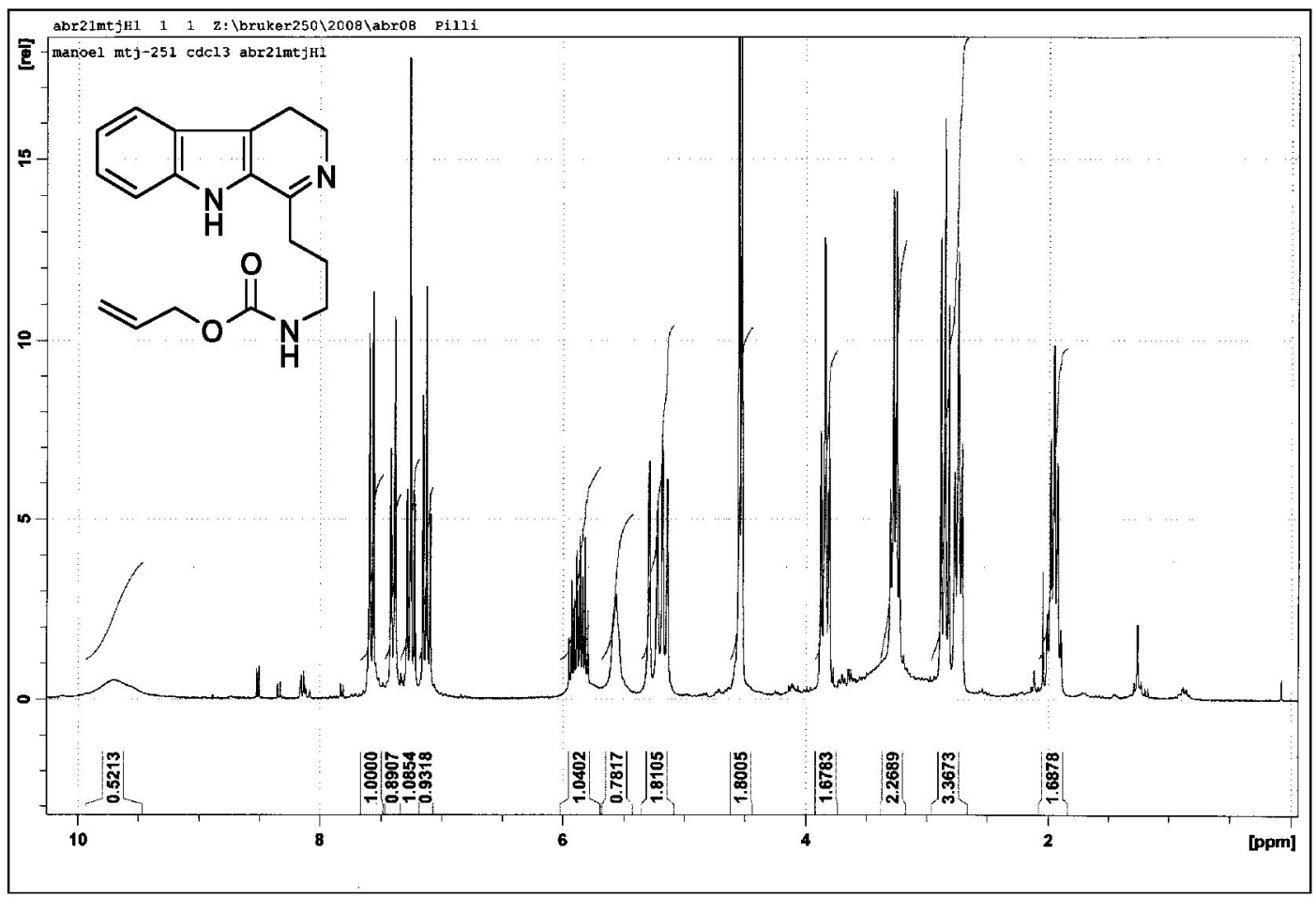

Figure S8. ${ }^{13} \mathrm{C}$ NMR for compound $9\left(62,5 \mathrm{MHz}, \mathrm{CDCl}_{3}\right)$.

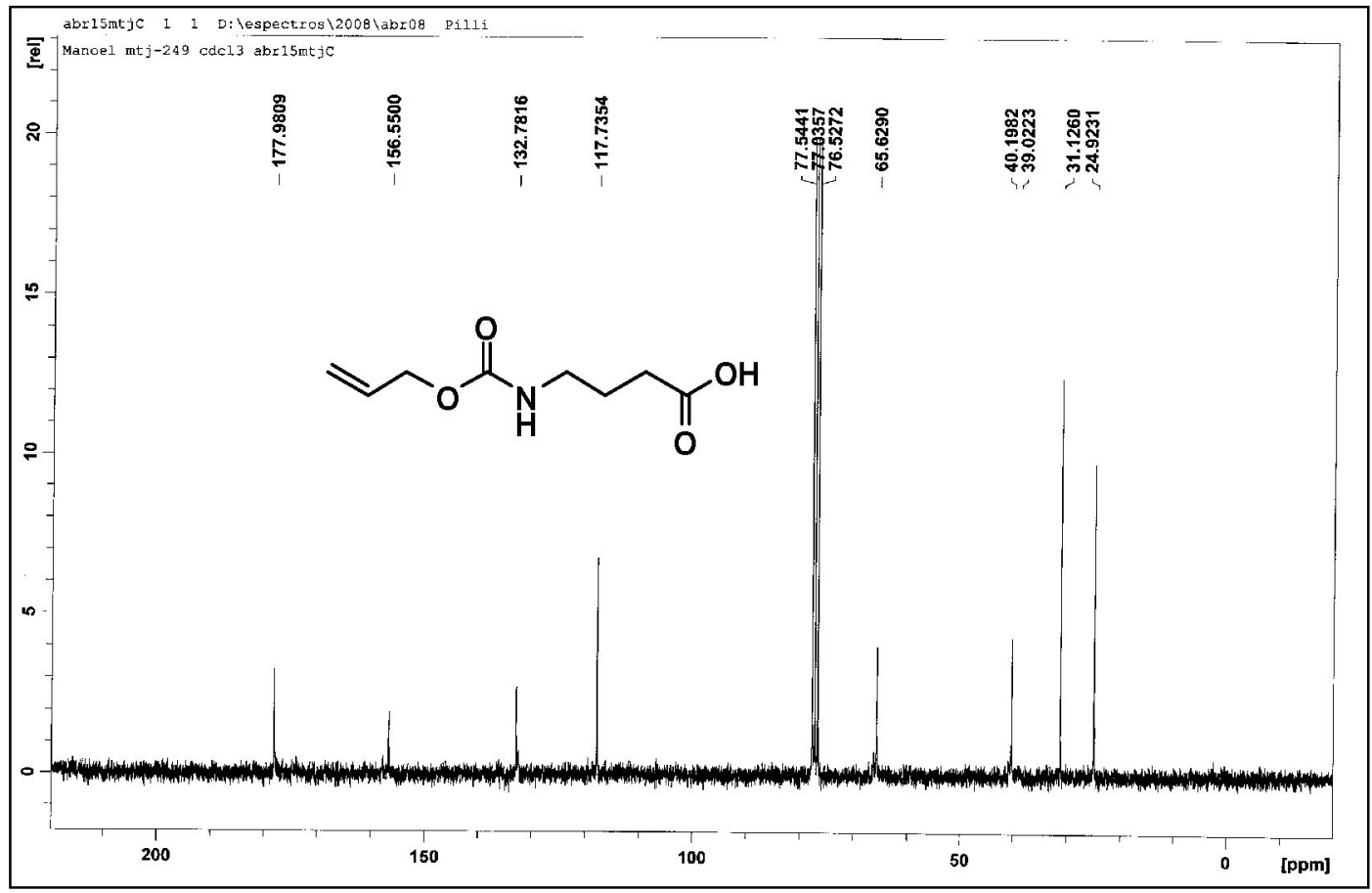

Figure S9. ${ }^{1} \mathrm{H}$ NMR for compound $10\left(250 \mathrm{MHz}, \mathrm{CD}_{3} \mathrm{OD}\right)$. 
4-\{[(Allyloxy)carbonyl $]$ amino $\}$ butanoic acid (6)

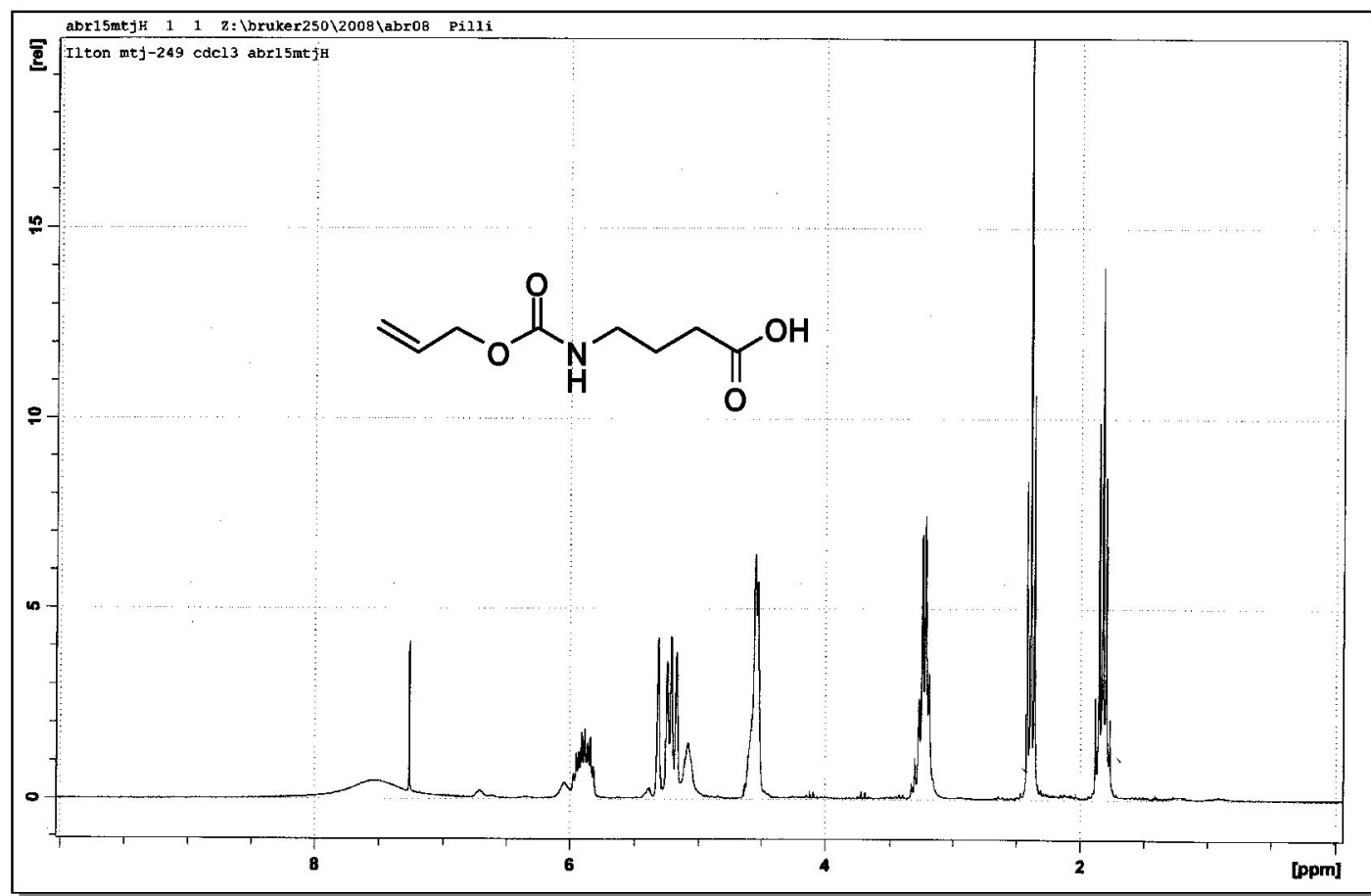

Figure S10. ${ }^{13} \mathrm{C}$ NMR for compound $\mathbf{1 0}\left(62,5 \mathrm{MHz}, \mathrm{CD}_{3} \mathrm{OD}\right)$.

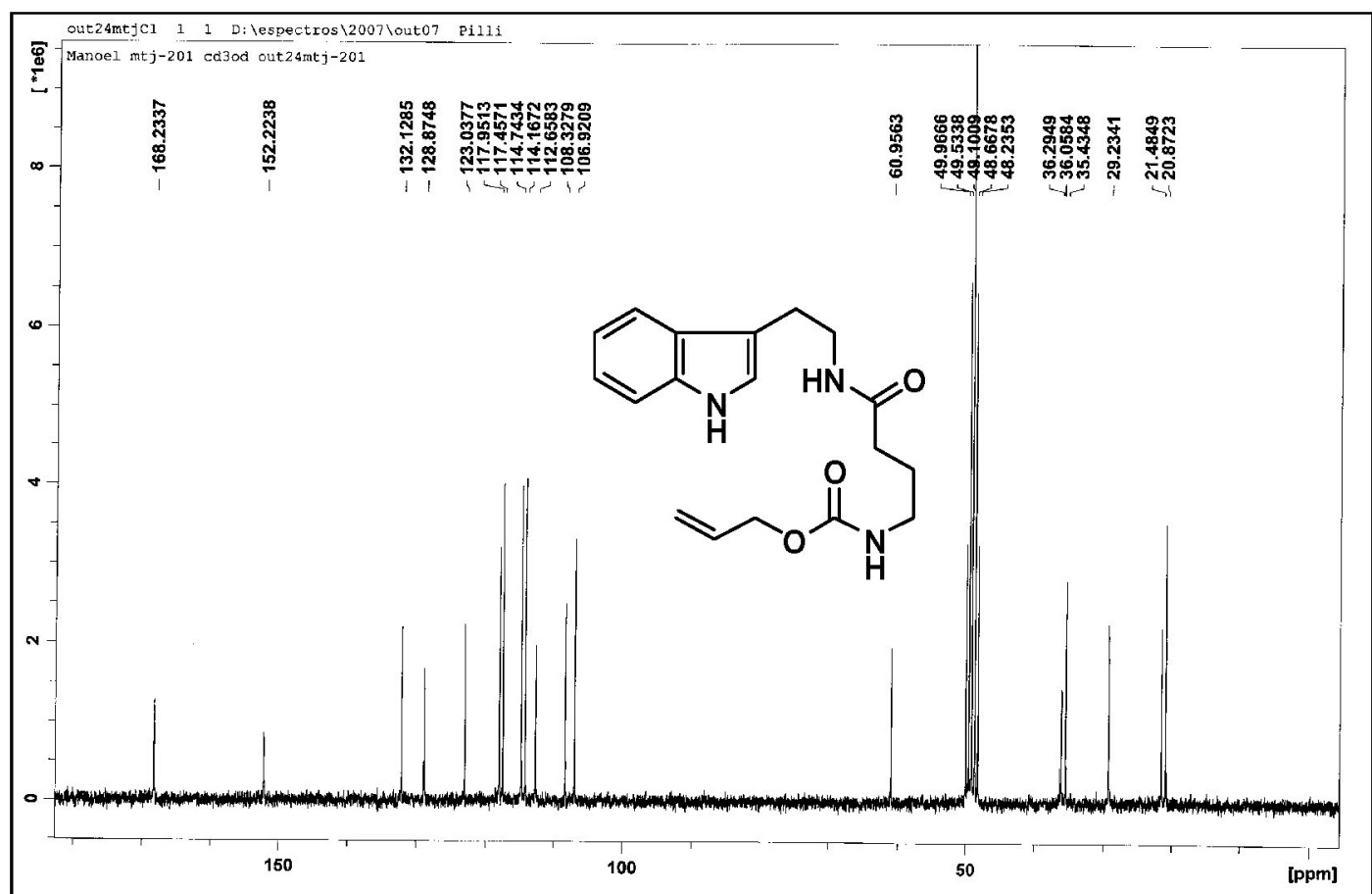

Figure S11. ${ }^{1} \mathrm{H}$ NMR for compound $11\left(250 \mathrm{MHz}, \mathrm{CD}_{3} \mathrm{OD}\right)$. 
Allyl (4-\{2-[1H-indol-3-yl)ethyl]amino)-4-oxobutyl)carbamate (4)

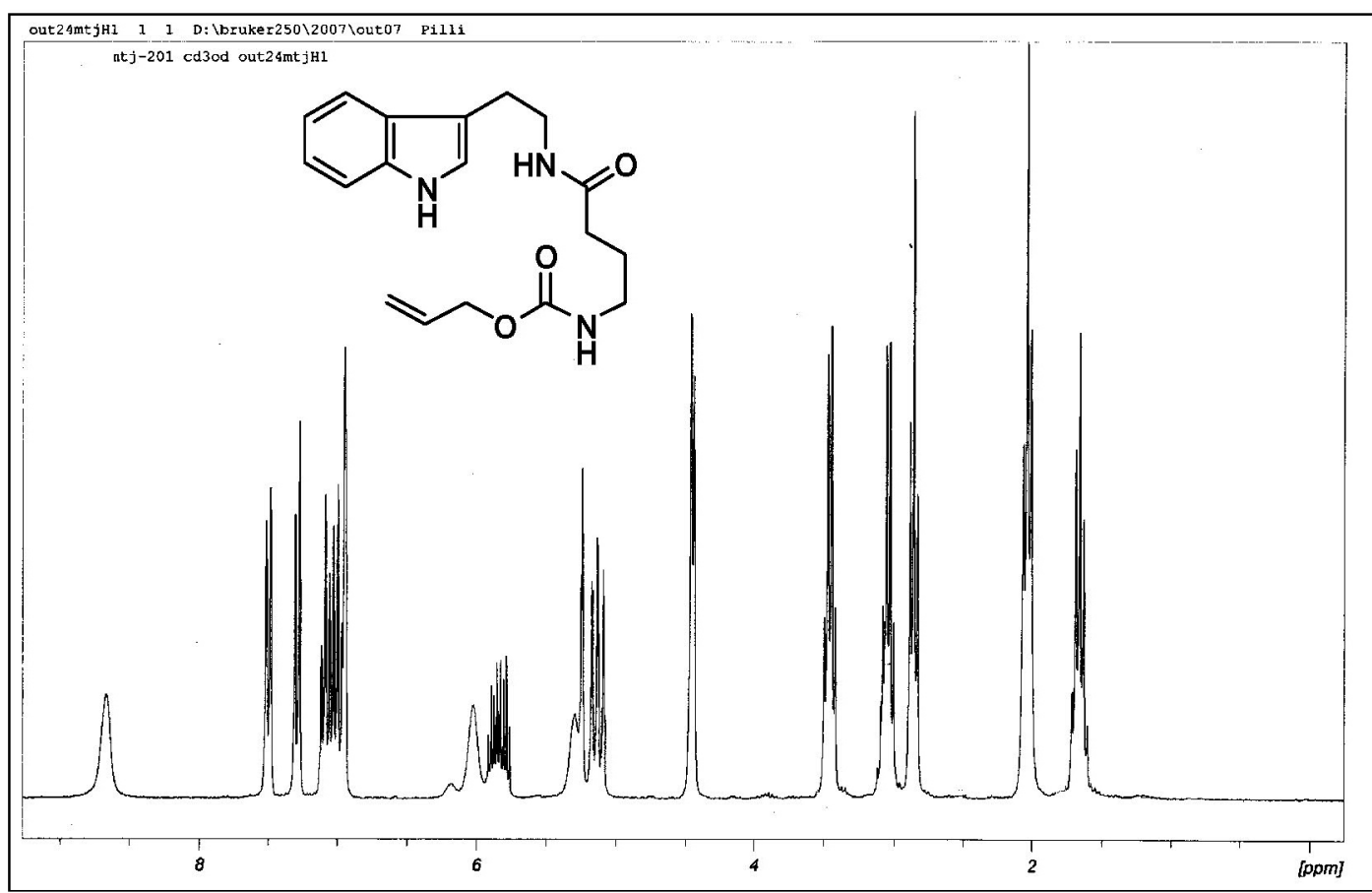

Figure S12. ${ }^{13} \mathrm{C}$ NMR for compound $11\left(62,5 \mathrm{MHz}, \mathrm{CD}_{3} \mathrm{OD}\right)$.

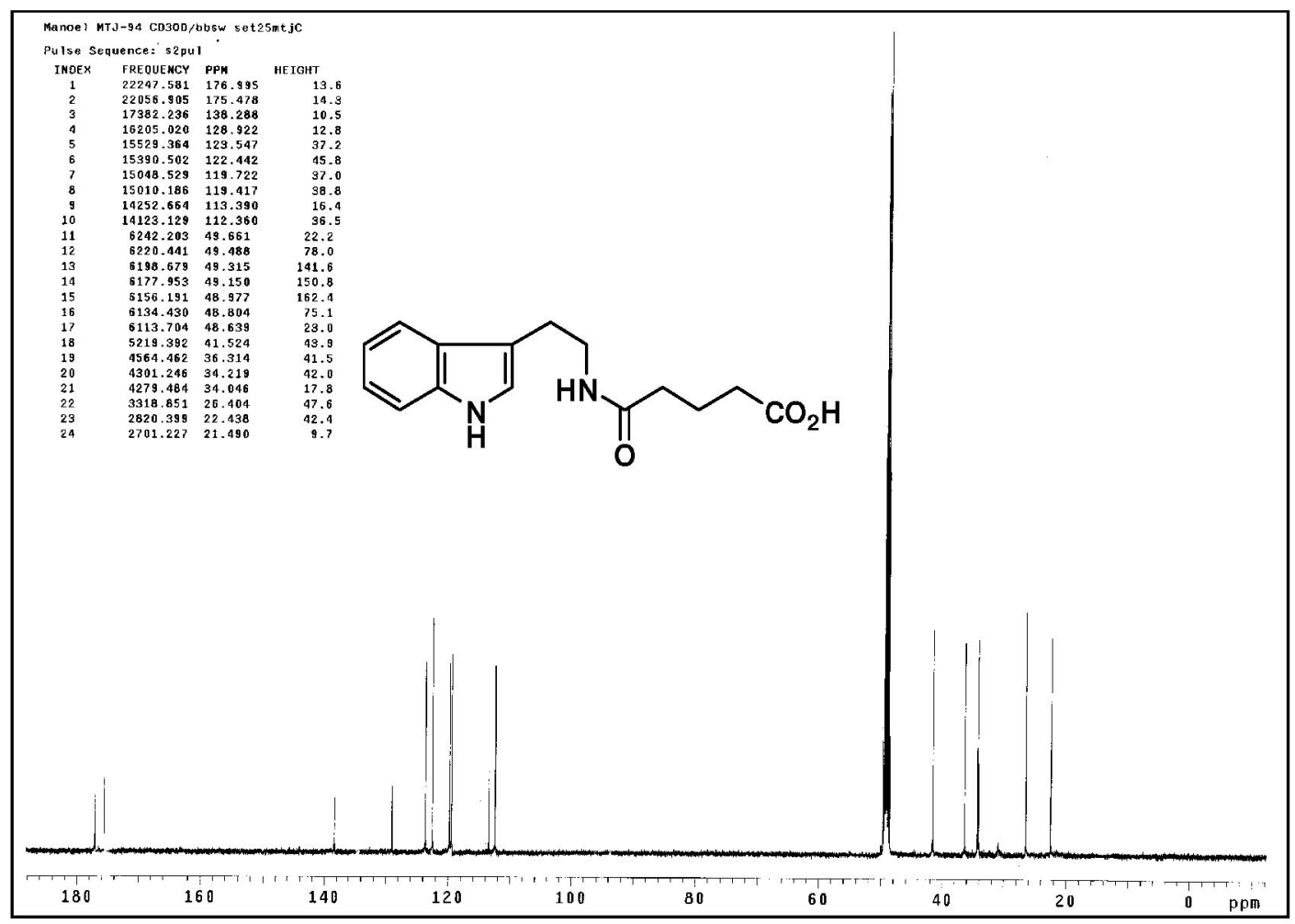

Figure S13. ${ }^{1} \mathrm{H}$ NMR for compound $1\left(250 \mathrm{MHz}, \mathrm{CD}_{3} \mathrm{OD}\right)$. 


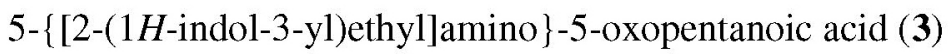

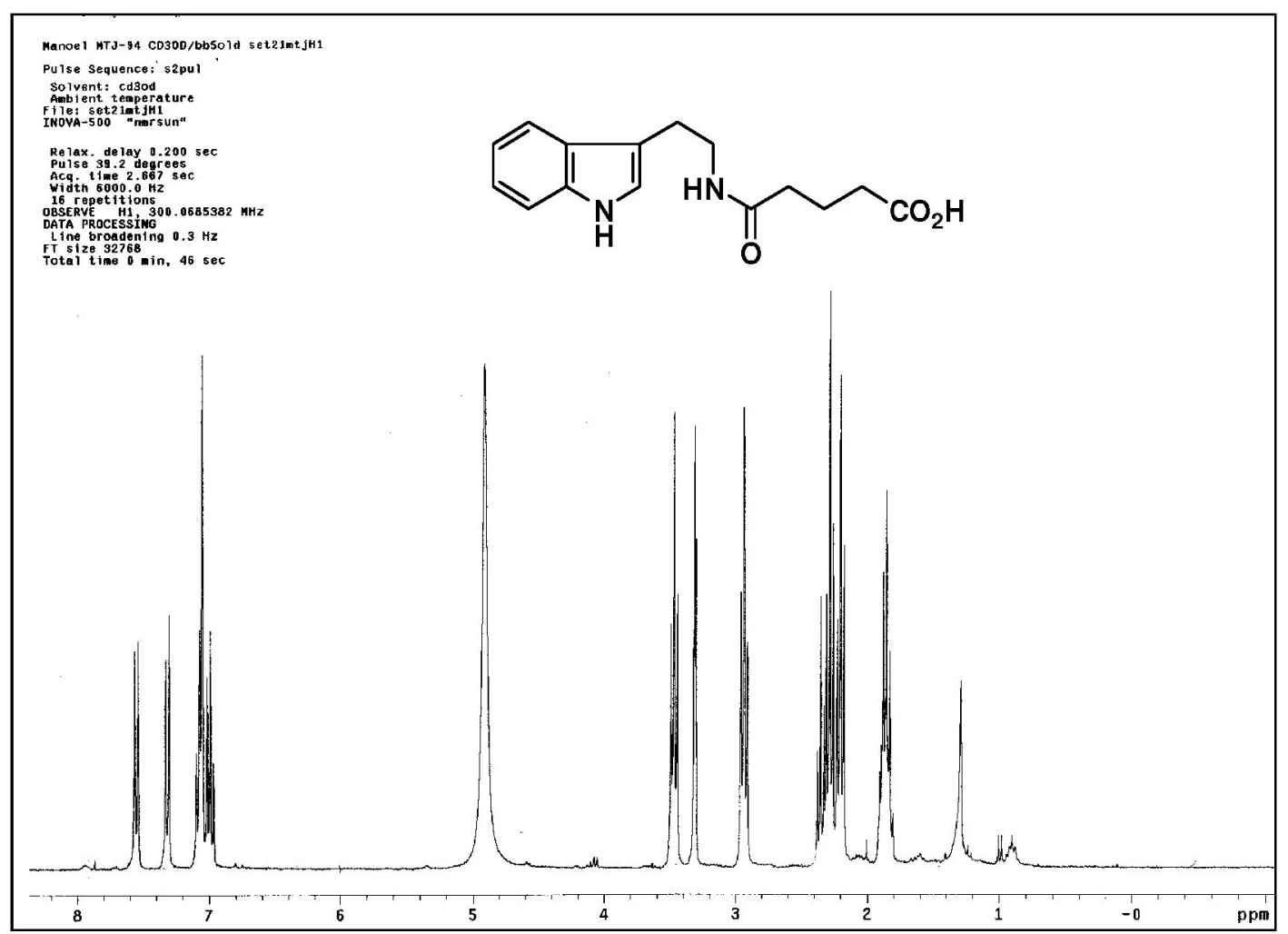

Figure S14. ${ }^{13} \mathrm{C}$ NMR for compound $1\left(62.5 \mathrm{MHz}, \mathrm{CD}_{3} \mathrm{OD}\right)$. 